\title{
Ustroj i djelovanje Dioničarskoga društva Lonjskopoljske željeznice u periodu Austro-Ugarske Monarhije
}

\author{
SINIŠA LAJNERT \\ Hrvatski državni arhiv \\ Zagreb, Hrvatska \\ slajnert@arhiv.hr
}

U radu autor na temelju arhivskih izvora, a s aspekta povijesti institucija, obrađuje ustroj i djelovanje Dioničarskoga društva Lonjskopoljske željeznice u periodu Austro-Ugarske Monarhije. Sjedište Društva, kao i većine vicinalnih željeznica, bilo je u Budimpešti. Poslove Dioničarskoga društva obavljali su glavna skupština dioničara, ravnateljstvo i nadzorni odbor. Pruge Društva bile su sljedeće: Dugo Selo - Novska i Banova Jaruga - Pakrac. Te privatne pruge bile su u državnoj eksploataciji, odnosno upravi. U Austro-Ugarskoj Monarhiji pruge Društva potpadale su pod nadležnost Poslovne uprave Kraljevskih ugarskih državnih željeznica u Zagrebu. Društvo je poslovalo s financijskim dobitkom.

Ključne riječi: Lonjskopoljska željeznica; pruga Dugo Selo - Novska; pruga Banova Jaruga - Pakrac; vicinalne željeznice; Austro-Ugarska Monarhija

\section{Uvod}

U članku su s aspekta povijesti institucija prikazani rezultati istraživanja ustroja i djelovanja Dioničarskoga društva Lonjskopoljske željeznice (Lonjavölgyi vasut részvénytársaság / Lonjathalbahn Actiengesellschaft) u periodu Austro-Ugarske Monarhije. ${ }^{1}$

\footnotetext{
1 Ponekad se u dokumentima željeznica spominje pod nazivom Vicinalna željeznica Lonjske doline ili Lonjsko-dolinska željeznica, a rjeđe Lonja-dolska željeznica.
} 
Članak se temelji u prvom redu na proučavanju sačuvanoga arhivskoga gradiva koje se nalazi u Hrvatskom državnom arhivu. Obrađeni su i predmetni zakonski propisi objavljeni u službenim glasilima, službeni shematizmi, dnevne tiskovine iz toga vremena te predmetna stručna i znanstvena literatura.

Vicinalne željeznice 2 , u koje je spadala i Lonjskopoljska željeznica, bile su željeznice lokalnoga (mjesnoga) karaktera kojima je osnovna svrha bila poduprijeti prometne i gospodarske interese određenoga područja. Ekspanzivni razvoj željezničke mreže na prostoru Kraljevine Hrvatske i Slavonije započeo je 13. lipnja 1880. donošenjem Zakona o željeznicama mjesnog interesa ${ }^{3}$ te njegove dopune iz 1888. godine. ${ }^{4}$ Ti su zakonski akti omogućili privatnom kapitalu izgradnju i eksploataciju željezničke mreže. Hrvatska željeznička mreža najveći razvoj dostigla je upravo onda kada je država odlučila njezinu izgradnju i eksploataciju prepustiti privatnom kapitalu, odnosno ekonomskom interesu (profitu). Tako je u travnju 1918. na prostoru Kraljevine Hrvatske i Slavonije bilo sveukupno $2390 \mathrm{~km}$ pruga - $980 \mathrm{~km}$ glavnih (901 km državnih željeznica i $79 \mathrm{~km}$ Južne željeznice) i $1410 \mathrm{~km}$ vicinalnih željeznica. ${ }^{5}$

Ustroj i poslovanje dioničarskih društava u ugarskom dijelu Monarhije regulirao je Zakonski članak XXXVII: Trgovački zakon, proglašen 16. svibnja 1875. godine. Dioničarska društva bila su osnovana onoga trenutka kad im je bila osigurana glavnica, kad su bila odobrena njihova pravila (statut) te kad je njihovo osnivanje zabilježeno u trgovačkom registru nadležnoga suda. Dioničarska društva osnivana su s unaprijed ustanovljenom glavnicom koja se sastojala od dionica. Vlasnici dionica jamčili su samo do iznosa dionica u svojem vlasništvu. Ustroj dioničarskih društava bio je sljedeći: glavna skupština (skup svih dioničara), ravnateljstvo i nadzorni odbor. ${ }^{6}$

Dioničarsko društvo Lonjskopoljske željeznice sa sjedištem u Budimpešti osnovano je 15. lipnja $1896 .{ }^{7}$ Njegove pruge Dugo Selo - Novska $(84,278 \mathrm{~km})$ i

\footnotetext{
2 Vïcinālan, -lna, -lno, lat. (vicinalis), obližnji, susjedan; vîcinālnā željeznica - sporedna željeznica (obično uskotračna) za lokalni promet. Vidi: „Vïcinālan”, u: KLAIĆ, Rječnik stranih riječi, 1420.

3 „Zakonski članak XXXI. zajedničkoga hrvatsko-ugarskoga sabora o željeznicah mjestnog interesa", Sbornik zakonah i naredabah. Godina 1880., 235-239.

4 Tzv. Vicinalni zakon iz 1880. mijenja se i dopunjuje 24. veljače 1888. Zakonskim člankom IV. iz 1888. o preinačenju i nadopunjenju Zakonskoga članka XXXI. od godine 1880. o željeznicah mjestnoga interesa. Usp. Sbornik zakonah i naredabah. Godina 1888., 185-191.

LAJNERT, „Dioničarsko društvo Slavonske vicinalne željeznice”, 161-162, 187-188.

6 Sbornik zakonah i naredabah. Godina 1875., 899-1016. S obzirom na neke pogreške u prvotno objavljenoj verziji Trgovačkoga zakona, naknadno je objavljena njegova ispravljena verzija. Usp. Sbornik zakonah i naredabah. Godina 1877., 525-642.

7 Compass. Finanzielles Jahrbuch für Oesterreich-Ungarn, 1901., 1223. Usp. Mihók'scher Ungarischer Compass, 1900./1901., 419-420.
} 
Banova Jaruga - Pakrac $(30,065 \mathrm{~km})$ puštene su u promet 29. studenog $1897 .{ }^{8}$ U Austro-Ugarskoj Monarhiji pruge Društva bile su u eksploataciji Kraljevskih ugarskih državnih željeznica.

Lonjskopoljska željeznica, koja je išla od Dugog Sela do Novske, a odvajala se od Banove Jaruge u Pakrac, spajala je bogatu Moslavinu sa Zagrebom te uvelike pomagala preopterećenoj liniji Zagreb - Sisak - Novska. ${ }^{9}$ Većim dijelom prolazila je kroz Bjelovarsko-križevačku županiju te je time otvorila prometu ne samo Moslavinu nego i druge šumske predjele. ${ }^{10}$ Veoma je važna činjenica da je pruga Novska - Dugo Selo - Zagreb bila oko 12,5 km kraća od pruge Novska - Sisak - Zagreb, čiji je dio Sisak - Zagreb - Savski Marof (Zidani Most) bio u vlasništvu Društva južnih željeznica ${ }^{11}$, te je od početka bila njezina konkurencija. Odlučeno je da se odmah pri gradnji od nje stvori tranzitna pruga za prijelazni promet na štetu Južnih željeznica. ${ }^{12}$ Cilj je bio

8 Compass. Finanzielles Jahrbuch für Oesterreich-Ungarn, 1907., 1129.

9 HR-HDA-757-OP, kut. 3, „Željeznice u Hrvatskoj i Slavoniji”, Hrvatska njiva (Zagreb), 26. 10. 1918., 706-709.

10 „Sitnice”, Šumarski list (Zagreb), 1. 5. 1896., 200.

11 Pruga Zidani Most / Zagreb - Sisak, u vlasništvu Društva južnih željeznica, najvećega i najmoćnijega željezničkoga dioničkog društva u Monarhiji, otvorena je za promet 1. listopada 1862. kao odvojak magistralne pruge Beč - Ljubljana - Trst. Usp. STULLI, Prijedlozi i projekti željezničkih pruga, 72-73, 92-93.

12 Uprava Kraljevskih ugarskih državnih željeznica obustavila je od 1. listopada 1909. uporabu peage prometa (tranzitni, provozni promet po postajama i prugama drugih željeznica reguliran ugovorima) na pruzi Južne željeznice Sisak - Zagreb. Uslijed toga napuštanja peažnoga prometa osobnih vlakova Kraljevskih ugarskih državnih željeznica koje su vozile između Broda i Zagreba Južna željeznica, kao vlasnica pruge Sisak - Zagreb, pobirala je od putnika posebne pristojbe. Konkretnije rečeno, putovanje na željeznici od postaja koje su se nalazile između Zemuna i Siska do Zagreba ili dalje stajalo je osim pojasne tarife Kraljevskih ugarskih državnih željeznica za istu prugu još 1,70 kruna u 1. razredu i 1,10 kruna u 2. razredu brzoga vlaka, a 0,80 kruna u 1. razredu, 0,50 kruna u 2. razredu i 0,40 kruna u 3. razredu osobnoga vlaka (u tiskanom izvorniku pogrešno je navedeno da je 3. razred skuplji od 2. razreda osobnog vlaka - op.a.). Osječka trgovačka komora, čim je saznala za tu anomaliju, podnijela je kraljevskom ugarskom ministru trgovine obrazloženu predstavku te zatražila da se putnici oslobode toga nepravednog plaćanja. Komora je pritom polazila s gledišta da je Zagreb glavni grad zemlje te je posve prirodno da je između njega i ostatka zemlje razvijen veoma živ osobni promet, koji se po geografskom položaju zemlje većinom kretao iz Slavonije. Teret koji je putnicima nametnula Južna željeznica za uporabu pruge Zagreb - Sisak za osobne vlakove Kraljevskih ugarskih državnih željeznica podnosili su dakle većinom putnici iz Slavonije. Treba reći da je država prilikom izgradnje Lonjskopoljske vicinalne željeznice na temelju odredbi Zakonskoga članka XIII. iz 1896. na pruzi Novska - Dugo Selo otkupila pravo djelomičnoga provoznog prometa za 1.000 .000 kruna (500.000 forinti). Pruga Lonjskopoljske vicinalne željeznice Novska - Dugo Selo bila je prirodni put za produženje glavne željezničke linije iz Zemuna, odnosno Broda do Zagreba te je bila oko $13 \mathrm{~km}$ kraća nego pruga preko Siska, a nalazila se u cijelosti u eksploataciji Kraljevskih ugarskih državnih željeznica. Kako je 98 km dugačka željeznička linija Novska - Dugo Selo ležala sasvim horizontalno u ravnici, dala se lako i pregraditi i preurediti za promet brzih osobnih vlakova. Da bi se ta nepravedna anomalija s provozom na liniji Južne željeznice Sisak - Zagreb uklonila, bilo je nužno da se pruga Lonjskopoljske željeznice Novska - Dugo Selo što prije upotrijebi za provoz osobnoga prometa vlakova Kraljevskih ugarskih državnih željeznica. Tim pitanjem bavila se na molbu osječke trgovačke komore i zagrebačka komora te je zaključila da će i ona poduprijeti njezin prijedlog. Usp. HR-HDA-757-OP, kut. 2, „Naše prometne prilike i neprilike”, Hrvatski branik list za politiku, javni život i gospodarstvo (Mitrovica), 24. 11. 1909., 2. 
ograničiti djelovanje Južne željeznice na prugu u njezinu vlasništvu Zagreb - Harmica, tj. do hrvatske granice, i na prugu Barcs - Pakrac ${ }^{13}$, koja je bila u njezinoj eksploataciji. Posao na toj pruzi stalno se razvijao. Da bi pruga bila sposobna za promet brzih vlakova i tranzitni promet, trebalo joj je pojačati donji i gornji stroj. ${ }^{14}$ Treba istaknuti da je Lonjskopoljskoj željeznici povezanost s Mađarskom osigurana spojem preko Dugog Sela na prugu Kraljevskih ugarskih državnih željeznica, tzv. žakanjsku prugu. Ona je početkom siječnja 1870. povezala Zákány (Budapest) preko Koprivnice, Križevaca i Dugog Sela sa Zagrebom. ${ }^{15}$ Od Zagreba dalje na zapad prema austrijskom dijelu Monarhije veza je, kao što je rečeno, osigurana prugom Zagreb - Savski Marof (Zidani Most) u vlasništvu Društva južnih željeznica. Spajajući se u Novskoj na glavnu prugu Kraljevskih ugarskih državnih željeznica koja je vodila prema istoku smjerom Novska - Gradiška - Nova Kapela Batrina - Brod (spoj s Bosnom) - Vrpolje Vinkovci - Ilača - Šid - Mitrovica - Ruma - Inđija - Zemun, ${ }^{16}$ Lonjskopoljska željeznica osigurala je vezu sa Srbijom. Istovremeno je od Novske preko Sunje u smjeru Dobrljina osigurana veza s Bosnom. ${ }^{17}$

\footnotetext{
13 Dozvolna izprava u pogledu izgradjenja i prometa Barcs-pakračke željeznice mjestnoga interesa izdana je 9. ožujka 1884. u Budimpešti. Koncesiju je dobio Henrik Benies. Iste godine koncesionar je osnovao Dioničarsko društvo vicinalne željeznice Barcs - Pakrac sa sjedištem u Budimpešti (Barcs-pakráczi vasut részvénytársaság Budapest / Barcs-Pakráczer Eisenbahn-Actiengesellschaft). Pruga Barcs - Pakrac puštena je u promet 18. kolovoza 1885. godine. Prema eksploatacijskom ugovoru između Društva južnih željeznica i Društva željeznice Barcs - Pakrac od 10. svibnja 1884., eksploataciju željeznice Barcs - Pakrac za cijelo vrijeme trajanja koncesije bez prava otkaza preuzelo je Društvo južnih željeznica. Ono je za vođenje prometa dobivalo $50 \%$ od bruto prihoda i $20 \%$ od viška bruto prihoda preko iznosa od 1.200 .000 kruna, a maksimalno $40 \%$ od bruto prihoda preko iznosa 1.800 .000 kruna. Društvo južnih željeznica jamčilo je koncesionaru prema eksploatacijskom ugovoru minimalni prihod od $600.000 \mathrm{kru}-$ na godišnje. Usp. Sbornik zakonah i naredabah. Godina 1887., 421-433; HR-HDA-79-UOZV, kut. 680, sv. 10-4, kor.br. 46209/1882., ur.br. 11033/1884.; kut. 848, sv. 10-4, kor.br. 38150/1885.; Mihók'scher Ungarischer Compass, 1900./1901., 400-401; „Barčko-pakračka željeznica”, Narodne novine (Zagreb), 18. 8. 1885., 2; HR-HDA-529-HDB, sv. 842/II, Dosje: Barč-Pakrac (dopis ur.br. 11863/42. koji je 21. veljače 1942. Odjel za željeznice, autopromet i brodarstvo Ministarstva prometa i javnih radova Nezavisne Države Hrvatske uputio u svezi s otkupom Barč-pakračke vicinalne željeznice Hrvatskoj državnoj banci u Zagrebu). Usp. i: STEHLIK, „Postanak i razvitak železnica”, 82, 87.

14 GORNIČIĆ-BRDOVAČKI, Razvitak željeznica u Hrvatskoj, 193-194.

15 LAJNERT, „Dioničarsko društvo vicinalne željeznice Križevci - Bjelovar - Virovitica - Barcs”, 19.

16 Državna pruga Zemun - Novska građena je po etapama. Pruga Dalj - Vinkovci - Brod otvorena je za promet 23. studenog 1878. (u početku samo za vojničke svrhe), Inđija - Mitrovica i Novi Sad - Zemun 10. prosinca 1883., Zemun - Savski most - Beograd (spoj sa Srbijom) 15. rujna 1884., Sunja - Nova Gradiška 10. siječnja 1888., Nova Gradiška - Brod 18. rujna 1889. i pruga Mitrovica Vinkovci 7. listopada 1891. godine. Usp. HR-HDA-79-UOZV, kut. 391, sv. 10-4, kor.br. 7322/1878., ur.br. 24265/1878.; kut. 680, sv. 10-4, kor.br. 47047/1883., ur.br. 50808/1883.; kut. 898, sv. 10-4, kor.br. 731/1888., ur.br. 40976/1889.; „Otvorenje javnoga prometa”, Narodne novine, 2. 1. 1888., 3; „Željeznička pruga Sunja-Nova Gradiška”, Narodne novine, 11. 1. 1888., 2; „Željeznica Vinkovci-Mitrovica”, Narodne novine, 7. 10. 1891.; 3; STEHLIK, „Postanak i razvitak železnica”, 82.

17 Pruga Sisak - Sunja - Dobrljin (spoj s Bosnom) otvorena je za promet 10. travnja 1882., a Sunja - Nova Gradiška 10. siječnja 1888. godine. Usp. „Željeznica od Siska u Dobrlin”, Narodne novine, 8. 4. 1882., 3; „Željeznica iz Siska u Dobrlin”, Narodne novine, 11. 4. 1882., 3; „Otvorenje
} 
Kao što se vidi, u Kraljevini Hrvatskoj i Slavoniji vladao je mješoviti sustav vlasništva nad željeznicama budući da su pored državnih ${ }^{18}$ postojale i privatne, tzv. vicinalne željeznice. ${ }^{19}$ Većina privatnih vicinalnih željeznica na prostoru Kraljevine Hrvatske i Slavonije bila je u eksploataciji Kraljevskih ugarskih državnih željeznica (privatne željeznice u državnoj upravi), a samo ih je nekoliko bilo u privatnoj upravi. ${ }^{20}$

\section{Osnutak Dioničarskoga društva Lonjskopoljske željeznice}

Dana 15. lipnja 1896. na konstituirajućoj glavnoj skupštini Dioničarskoga društva Lonjskopoljske željeznice u Budimpešti donesena su temeljna pravila Društva. U smislu čl. 21. koncesijske isprave ozakonjene Zakonskim člankom XIII. iz 1896., utemeljili su grof Artur Berchtold, vlasnik velikih šumskih kompleksa i

javnoga prometa”, Narodne novine, 2. 1. 1888., 3; „Željeznička pruga Sunja-Nova Gradiška”, Narodne novine, 11. 1. 1888., 2.

18 Godine 1918. na prostoru Kraljevine Hrvatske i Slavonije postojalo je 980 km glavnih javnih željeznica. Prva javna željeznica Sisak - Zagreb - Zidani Most puštena je u promet 1862. godine. Slijedile su pruge: Zagreb - Karlovac, Zákány - Zagreb, Erdut - Dalj - Osijek, Karlovac - Rijeka - zemaljska granica, Dalj - Brod, Vrpolje - Šamac, Sisak - Galdovo, Brod - Bosanski Brod, Sisak Dobrljin, Novi Sad - Zemun, Inđija - Mitrovica, Zemun - Beograd, Sunja - Nova Gradiška, Nova Gradiška - Brod, zagrebačka spojna pruga Južni kolodvor i Državni kolodvor, Borovo - Vukovar, Vinkovci - Mitrovica, Ogulin - Plaški. To je od 1862. do 1914. iznosilo 971 km. Ako se tome pribroji još nekoliko spojnih i pretovarnih kolosijeka, cjelokupna duljina iznosila je $980 \mathrm{~km}$. Usp. LAJNERT, „Dioničarsko društvo vicinalne željeznice Križevci - Bjelovar - Virovitica - Barcs”, 18.

19 Godine 1918. na prostoru Kraljevine Hrvatske i Slavonije postojalo je 1410 km vicinalnih željeznica. Prva je 1885. izgrađena željeznica Barcs - Pakrac, koja je jedina bila pod upravom Južne željeznice. Slijedile su Zagorska željeznica, Vinkovci - Brčko, Ruma - Vrdnik, Belišće - Kapelna, Varaždin - Golubovec, Osijek - Našice, Križevci - Bjelovar, Szt. Lörincz - Našice, Viljevo Noskovci, Dugo Selo - Novska i Banova Jaruga - Pakrac, Belišće - Prandanovci, Bjelovar - Mišulinovac, Mišulinovac - Virovitica, Zagreb - Samobor, Ruma - Klenak, Vinkovci - Županja kao dio Sjedinjene Dravsko-posavske vicinalne željeznice, Osijek - Đakovo - Vrpolje, Vörösmajur - Voćin, Vrginmost - Karlovac, Belišće - Osijek, Petrovaradin - Beočin, Kloštar - Virje, Osijek - Vinkovci, Vukovar - Šid - Rača, Virje - Koprivnica, Bjelovar - Velika Pisanica, Velika Pisanica - Garešnica Grubišno Polje, Karlovac - Bubnjarci, Požega - Velika te konačno 1916. Zabok - Stubica. Vidi: Isto.

20 Na prostoru Kraljevine Hrvatske i Slavonije postojala su sljedeća dioničarska društva čije su željeznice bile u državnoj upravi: Dioničarsko društvo željeznice Čakovec - Zagreb, Dioničarsko društvo vicinalne željeznice Vinkovci - Brčko, Dioničarsko društvo vicinalne željeznice Varaždin - Golubovec, Dioničarsko društvo Slavonske vicinalne željeznice, Dioničarsko društvo željeznice Križevci Bjelovar - Virovitica - Barcs, Dioničarsko društvo vicinalne željeznice Szt. Lörincz - Slatina - Našice, Dioničarsko društvo Lonjskopoljske željeznice, Dioničarsko društvo lokalne željeznice Ruma - Klenak, Dioničarsko društvo Sjedinjenih Dravsko-posavskih vicinalnih željeznica (Dioničarsko društvo mjesne željeznice Vinkovci - Županja - savska obala i Dioničarsko društvo vicinalne željeznice Osijek - Đakovo - Vrpolje), Dioničarsko društvo Prve jugozapadne krajiške mjesne željeznice, Dioničarsko društvo vicinalne željeznice Petrovaradin - Beočin, Dioničarsko društvo Dunavsko-posavske vicinalne željeznice, Dioničarsko društvo vicinalne željeznice Zabok - Stubica, Dioničarsko društvo Rumsko-vrdničke lokalne željeznice, Dioničarsko društvo lokalne željeznice Pécs - Donji Miholjac. Iznimka su bile pruge Vicinalne željeznice Zagreb - Samobor i Slavonsko-podravske vicinalne željeznice, koje su vodile eksploataciju u svojoj režiji (privatne željeznice u privatnoj upravi). Pruge Vicinalne željeznice Barcs - Pakrac bile su u eksploataciji Društva južnih željeznica. 
poljoprivrednih dobara u Moslavini te pecara žeste u Prečecu, i kointeresenti ${ }^{21}$, kao koncesionari željeznice Dugo Selo - Novska i pobočne pruge Banova Jaruga - Pakrac, dioničarsko društvo pod imenom Lonjavölgyi vasut részvénytársaság (Dioničarsko društvo Lonjskopoljske željeznice) te na njega prenijeli sva prava i sve obveze što su ih na temelju spomenute koncesijske isprave stekli odnosno preuzeli. Svrha Društva bila je: izgraditi i u prometu držati od Dugog Sela do Novske projektiranu željeznicu i pobočnu prugu od Banove Jaruge do Pakraca kao parovoznu željeznicu; graditi i u prometu držati sve glavne, pobočne i obrtne željezničke pruge koje bi Društvo ubuduće gradilo, nabavilo ili uzelo u zakup (na temelju ugovora ili koncesijske isprave ili s posebnim odobrenjem visoke državne vlade). Predviđeno je da bi poduzeće postojalo 90 godina računajući od datuma koncesijske isprave. Na temelju čl. 6. Temeljnih pravila Dioničarskoga družtva Lonjskopoljske željeznice iz 1896., sjedište mu je bilo u Budimpešti, a službeni poslovni jezik mađarski. Društvenim poslovima upravljali su glavna skupština i ravnateljstvo (9-15 članova). Postojao je i nadzorni odbor (3-5 članova), koji je u smislu Trgovačkoga zakona obnašao sva prava i dužnosti koji su mu pripadali. Kraljevska ugarska vlada imala je nadzorno pravo nad Društvom. Vlada je imala pravo preko svojega izaslanika ispitati i kontrolirati poslovodstvo i upravu željeznice. Organ vlade imao je pravo sudjelovati u ravnateljstvu, u povjerenstvima i odborima koje izabere ravnateljstvo, kao i na glavnoj skupštini, mogao je protuzakonite i za državne interese štetne, s koncesijskom ispravom nesuglasne odredbe suspendirati do daljnjega ministrova rješenja. Temeljna društvena glavnica ustanovljena je u nominalnoj vrijednosti na 4.970.000 forinti. Za nabavu te glavnice izdano je 7350 komada temeljnih dionica po 200 forinti odnosno 400 kruna koje su glasile na donosioca u ukupnoj nominalnoj vrijednosti od 1.470 .000 forinti, i 17500 komada prvenstvenih dionica po 200 forinti odnosno 400 kruna koje su glasile na donosioca u ukupnoj nominalnoj

\footnotetext{
$21 \quad$ Prema nekim autorima, molbe za dodjelu koncesija za gradnju pruga kroz Moslavinu podnijeli su još 1886. grof Artur Berchtold i mađarski industrijalac Vilim Deutsch, vlasnik kupališta u Lipiku i ribnjaka u Poljani. Grof Berchtold tražio je koncesiju za gradnju pruge između Dugog Sela i Novske, a Deutsch za gradnju pruge od Banove Jaruge do Pakraca. S obzirom na zajedničke interese, Deutsch je svoje pravo na koncesiju prenio na grofa Berchtolda, koji je time postao nositelj koncesije za obje pruge. Uz Berchtolda, glavni su dioničari bili grof Janković, grof Teleki, barun Tukory, zagrebački nadbiskup i Kaptol. Dioničar Društva bio je i banski savjetnik Márk Aurél Fodróczy, predstavnik Zemaljske vlade u Zagrebu. Usp. BUNIJEVAC, „Povijest”, 5-6.
} 
vrijednosti od 3.500.000 forinti. Za pokriće temeljnih dionica ${ }^{22}$ služili su sljedeći doprinosi: ${ }^{23}$

\begin{tabular}{|l|r|}
\hline Ministarstva & $\begin{array}{r}204.000 \text { forinti za besplatno otpremanje } \\
\text { pošte, 500.000 forinti za djelomični otkup } \\
\text { prijelaznoga prometa i 77.200 forinti kao } \\
\text { doprinos iz državne cestovne zaklade }\end{array}$ \\
\hline $\begin{array}{l}\text { 2. Kraljevsko ugarsko ministarstvo za } \\
\text { poljodjelstvo }\end{array}$ & 60.000 forinti \\
\hline 3. Kr. zemaljska vlada u Zagrebu & 160.000 forinti \\
\hline Županije & 112.000 forinti \\
\hline 4. Bjelovarsko-križevačka županija & 10.000 forinti \\
\hline 5. Zagrebačka županija & 50.000 forinti \\
\hline 6. Požeška županija & 10.000 forinti \\
\hline 7. Slob. i kr. glavni grad Zagreb & 45.000 forinti \\
\hline Općine & 40.000 forinti \\
\hline 8. Općina Križevci & 9.000 forinti \\
\hline 9. Općina Gradiška & 5.000 forinti \\
\hline 10. Općina Kutina & 4.000 forinti \\
\hline 11. Općina Popovača
\end{tabular}

22 Prema izdanim koncesijama, koncesionar je bio dužan osnovati dioničarsko društvo. Ono je za gradnju željeznice bilo ovlašteno pribavljati kapital izdavanjem dionica ili obveznica u koncesijom određenoj visini. Kapital društva bio je osnovni (temeljni) i prioritetni (prvenstveni). Osnovne (temeljne) dionice izdavane su osobama i tijelima lokalne samouprave zainteresiranima za gradnju pruge. No kako osnovni kapital prikupljen izdavanjem temeljnih dionica nije bio dovoljan, trebalo je privući i poduzetnike koji su tražili priliku za povoljan plasman kapitala. Stoga su izdavane prioritetne (prvenstvene) dionice i obligacije kojima je koncesijom i statutima društava prvenstveno zajamčena dividenda i amortizacija. Temeljne dionice nisu uživale to jamstvo jer se smatralo da su njihovi posjednici dovoljno honorirani već time što su dobili svoju željeznicu. Vidi: LAJNERT, „Dioničarsko društvo vicinalne željeznice Križevci - Bjelovar - Virovitica - Barcs”, 17-18.

23 HR-HDA-78-PRZV, kut. 499, sv. 6-14, ur.br. 2983/1896.

24 U Temeljnim pravilima Društva iz 1896. nalazi se podatak da je doprinos Zagrebačke županije iznosio 10.000 forinti, a u Stenografskom zapisniku 168. sjednice Sabora Kraljevine Hrvatske, Slavonije i Dalmacije od 25. siječnja 1897. (interpelacija dr. Ivana Ružića) navodi se da je doprinos Zagrebačke županije iznosio 110.000 forinti. Vidi: HR-HDA-78-PRZV, kut. 1183, Interpelacije, ur.br. 138/1897. Neobično je da je Zagrebačka županija, kao jedna od najbogatijih na prostoru Kraljevine Hrvatske i Slavonije te jedna od glavnih interesenata za gradnju pruge, doprinijela samo s 10.000 forinti. Međutim, za povjerovati je da su Temeljna pravila Društva točna, jer ukupan zbroj doprinosa države, Kraljevske zemaljske vlade, županija i općina za pokriće temeljnih dionica, s navedenih 10.000 forinti Zagrebačke županije, zaista iznosi navedenih 1.306 .700 forinti. Zajedno s prikupljenih 163.300 forinti od privatnih stranaka, zbroj iznosi točno 1.470 .000 forinti, kolika je uistinu i bila vrijednost izdanih temeljnih dionica. Na kraju krajeva, navedena Temeljna pravila odobrio je svojim potpisom i ministar trgovine u Budimpešti, čime je potvrdio točnost navedenih podataka. Treba spomenuti da se u interpelaciji Ivana Ružića na Saboru, osim podatka o 110.000 forinti doprinosa Zagrebačke županije, navodi i krivi naziv Bjelovarsko-križevačke županije (doprinos od 112.000 forinti). On je naziva Karlovačko-varaždinska županija, što je uistinu neobično. Za pretpostaviti je da je stenograf njegove riječi krivo zapisao. 


\begin{tabular}{|l|l|}
\hline 13. Općina Križ & 4.000 forinti \\
\hline 14. Općina Ludina & 4.000 forinti \\
\hline 15. Općina Ivanić & 3.000 forinti \\
\hline 16. Općina Lipovljani & 3.000 forinti \\
\hline 17. Općina Pakrac & 3.000 forinti \\
\hline 18. Općina Novska & 2.000 forinti \\
\hline 19. Općina Lipik & 1.500 forinti \\
\hline
\end{tabular}

Na temelju Zakonskoga članka IV. iz 1888. o preinačenju i nadopunjenju Zakonskoga članka XXXI. od godine 1880. o željeznicah mjestnoga interesa od 24. veljače 1888., gradnju vicinalnih željeznica mogli su podupirati država, municipiji ${ }^{25}$ i općine. $^{26}$

Doprinosi države, Kraljevske zemaljske vlade, županija i općina iznosili su 1.306.700 forinti, a od privatnih stranaka prikupljeno je 163.300 forinti, sveukupno dakle 1.470.000 forinti. Osim kraljevskih ugarskih ministarstava u Budimpešti i Kraljevske zemaljske vlade u Zagrebu, interes za gradnju tih pruga imale su hrvatsko-slavonske županije, grad Zagreb i neke općine. Od županija je glavni interesent bila Bjelovarsko-križevačka jer je oko $60 \mathrm{~km}$ pruge prolazilo kroz nju, a drugi dio kroz Požešku i Zagrebačku županiju. Zbog toga je Bjelovarsko-križevačka županija dala najveći doprinos. Od općina su najveći doprinos dali Križevci, a najmanji Lipik. Temeljna pravila Društva zajedno s tvrtkom ubilježena su 11. rujna 1896. kod budimpeštanskoga Kraljevskoga trgovačkoga i mjenbenoga sudbenog stola. ${ }^{27}$

Na konstituirajućoj glavnoj skupštini Dioničarskoga društva Lonjskopoljske željeznice bio je i Teodor Georgiević, kraljevski podžupan Kraljevske županijske oblasti u Bjelovaru. On je 17. lipnja 1896. izvijestio grofa Dragutina Khuen-Héderváryja, bana Kraljevine Hrvatske, Slavonije i Dalmacije, da su iz područja Trojedne Kraljevine u ravnateljstvo Društva imenovani grof Artur Berchtold ${ }^{28}$, narodni zastupnik Đuro Dedović, podžupani Slavko pl. Cuvaj i Teodor Georgiević te narodni zastupnik dr. Svetislav Šumanović, a u nadzorno vijeće tajnik Trgovačko-obrtničke komore u Osijeku Nikola A. Plavšić i nadšumar Adolf Hercl. Za predsjednika ravnateljstva izabran je grof Berchtold, a za potpredsjednike Đuro Dedović i veletržac Jakov Has. Prioritetne obveznice nalazile su se isključivo u rukama graditelja željeznice Ivana Horskog 29 . U egzekutivni odbor izabrani

\footnotetext{
25 Munìcīpij, lat. (municipium, gradić), grad sa samostalnom gradskom upravom. Vidi: „Munìcīpij”, u: KLAIĆ, Rječnik stranih riječi, 916.

26 Sbornik zakonah i naredabah. Godina 1888., 185-191.

27 HR-HDA-78-PRZV, kut. 499, sv. 6-14, ur.br. 2983/1896.

28 U arhivskim i tiskanim izvorima grof Artur Berchtold spominje se i kao Arthur Berchthold te Artur Berthold.

29 U Narodnim novinama iz prosinca 1897. objavljen je podatak da je Ivan Horsky dotad (proteklih petnaest godina) sagradio nekoliko važnih željeznica, i to slavonsku, Inđija - Mitrovica, Brod
} 
su Đuro Dedović, Jakov Has, dr. Rafael Neuman kao pravni zastupnik željezničkoga društva, a kao zamjenik Šandor Beimel. Kraljevski podžupan Georgiević predložio je na skupštini da se u statut Društva uvrsti pravo bana Kraljevine Hrvatske, Slavonije i Dalmacije da imenuje jednoga člana u ravnateljstvo. On je također zahtijevao da se sazivi glavnih skupština, bilance itd. proglašavaju u službenim Narodnim novinama te da se pravila Društva tiskaju i na hrvatskom jeziku. Svi njegovi prijedlozi bili su jednoglasno prihvaćeni. ${ }^{30}$

\section{Izgradnja pruga Dugo Selo - Novska i Banova Jaruga - Pakrac}

Konačnom i dugo očekivanom početku izgradnje pruge Dugo Selo Novska prethodili su znatno raniji pokušaji njezine realizacije. Tako je npr. već 1887. Konzorcij željezničke pruge Dugo Selo - Novska u svezi s njezinom izgradnjom uputio podnesak Kraljevskoj županijskoj oblasti u Bjelovaru. U podnesku se napominje da je Konzorcij, po nalogu Kraljevskoga ugarskog ministarstva javnih radova i prometa iz Budimpešte ${ }^{31}$, izradio detaljnu osnovu željezničke pruge Dugo Selo - Križ - Kutina - Novska te se uskoro očekivala rasprava o definitivnoj koncesiji. Ta je pruga išla počevši od Lonje do Ilove usporedno s glavnom slavonskom cestom, koja se s obzirom na otežanu nabavu šljunka održavala uz velike troškove. U podnesku se napominje da bi se izgradnjom te pruge trošenje spomenute ceste smanjilo za pola te bi tako bila umanjena i potreba njezina popravljanja. I sama cijena šljunka bila bi znatno snižena. Šljunak je tada stajao 6-7 forinti po kubnome metru, a kad bi se prevozio željeznicom, stajao bi najviše 3 forinte po kubnome metru. Kako je izgradnja te pruge bila u osobitom interesu Bjelovarsko-križevačke županije, Konzorcij je zamolio županijsku skupštinu da sudjeluje u nabavi temeljnih dionica pruge svotom koja bi razmjerno odgovarala uštedi koja bi se korištenjem pruge ostvarila u pogledu održavanja ceste. Konzorcij je napomenuo da je kod svih zainteresiranih za tu prugu prilikom njihovih zajedničkih sastanaka u Ivanić-Gradu, Križu, Popovači i Kutini 1886. naišao na veliko zanimanje. Od pruge se očekivao veliki tranzitni promet te samim time i sigurna zarada. S obzirom na sve rečeno, kao i na činjenicu da je od $80 \mathrm{~km}$ te pruge teritorijem

- Dalj, Šamac - Vrpolje - Mikanovci, i u Bosni Žepče - Zenica. Trenutačno se spremao za gradnju projektiranih pruga Osijek - Đakovo - Vrpolje i Pakrac - Požega. Vidi: „Lonjska željeznica”, Narodne novine, 2. 12. 1897., 4.

30 HR-HDA-78-PRZV, kut. 499, sv. 6-14, ur.br. 2983/1896. Iz dokumenta nije jasno tko je od navedenih na konstituirajućoj glavnoj skupštini Društva bio dioničar, a tko opunomoćenik dioničara.

31 Ministarstvo za javne radnje i komunikacije u Budimpešti (Közmunka-és Közlekedésügyi Minisztérium / Kön. ung. Ministerium für öffentliche Arbeit und Communication) bilo je od Austro-ugarske nagodbe 1867. pa do 1889. nadležno za poslove željeznica u ugarskom dijelu Monarhije, a time i za Hrvatsku i Slavoniju. Od 1889. do 1918. za poslove željeznica zaduženo je Ministarstvo trgovine u Budimpešti (Kereskedelmi Minisztérium / Kön. ung. Handels-Ministerium). 
Bjelovarsko-križevačke županije prolazilo $50 \mathrm{~km}$, Konzorcij se nadao povoljnom rješenju svoje molbe. Nabava temeljnih dionica tako nije izgledala kao žrtva, nego kao sigurno ulaganje. ${ }^{32}$

Skupština Bjelovarsko-križevačke županije, razmatrajući molbu Konzorcija željezničke pruge Dugo Selo - Novska, zaključila je 24. svibnja 1887. da se njezina gradnja što toplije preporuči. Kraljevska županijska oblast u Bjelovaru poslala je 1. lipnja 1887. Kraljevskoj zemaljskoj vladi u Zagrebu podnesak Konzorcija. Vlada je obaviještena da Konzorcij traži materijalnu potporu, no županija trenutačno nije mogla ništa poduzeti jer još uvijek nije bila izdana koncesija. Uviđajući veliku korist od te pruge, predložila je Kraljevska županijska oblast podnesak Konzorcija skupštini te županije, koja je zaključila da se izgradnja pruge preporuči na mjerodavnom mjestu. Kraljevska zemaljska vlada zamoljena je da se kod Kraljevskoga ugarskog ministarstva za javne radnje i komunikacije zauzme za dobivanje koncesije i izgradnju pruge. Kraljevska županijska oblast najavila je da će nastojati nagovoriti područne općine na svaku moguću potporu toj željeznici, npr. ustupanjem zemljišta bez naplate, a pučanstvo i imovne općine na nabavu dionica. ${ }^{33}$

Prvi politički ophod ${ }^{34}$ vicinalne željeznice Dugo Selo - Novska određen je otpisom kraljevskoga ugarskog ministra za javne radnje i komunikacije već 6. lipnja 1887. pod brojem 13944, a održan je 22. lipnja 1887. i idućih dana. Ophodu su nazočili predstavnici Kraljevskoga ugarskog ministarstva za javne radnje i komunikacije (Ivan Bally kao predsjednik ophodnoga povjerenstva), Carskoga i kraljevskoga zajedničkog ministarstva rata, Kraljevske zemaljske vlade, Kraljevskih ugarskih državnih željeznica, molitelja koncesije (Franjo Peyer ${ }^{35}$ ) te zainteresiranih oblasti. Uz odgovarajuće primjedbe i prijedloge, zapisnik je na kraju potpisan. ${ }^{36}$

Koncesijska rasprava ${ }^{37}$ u vezi sa željeznicom Dugo Selo - Novska održana je 19. studenog 1887., o čemu je sastavljen i povjerenstveni zapisnik. Uime

\footnotetext{
32 HR-HDA-79-UOZV, kut. 848, sv. 10-4, kor.br. 27673/1886., ur.br. 23158/1887.

33 Isto.

34 U izvornim dokumentima koriste se izrazi politički ophod (politička ophodnja) i tehničko-redarstveni ophod (policijsko-tehnički ophod). Politički ophod željeznice održavan je radi dobivanja građevinske dozvole, a tehničko-redarstveni ophod za izdavanje uporabne dozvole.

35 U zapisnicima o ophodu navodi se kao Franjo Payer.

36 HR-HDA-79-UOZV, kut. 2856, predmet X. 1898/204, sv. 10-4, kor.br. 10484/1894., ur.br. $72409 / 1896$.

37 U izvornim dokumentima koriste se izrazi dozvolbena rasprava, dozvolbena isprava, dozvolna isprava i dozvolbenik, odnosno dozvolbena tvrtka. Riječ je o koncesijskoj raspravi, koncesijskoj ispravi (koncesiji) i koncesionaru. Lat. (isp. koncedirati), 1. ugovor kojim država ili municipalna vlast, pod stanovitim uvjetima, daje u eksploataciju svoja poduzeća ili zemlju s pravom vađenja korisnih ruda, gradnje poduzeća itd.; 2. sámo poduzeće, organizirano na temelju koncesije; 3. dopuštenje, ustupanje, ustupak, povlastica; 4. odobrenje za vođenje obrta, dozvola za obavljanje neke djelatnosti. Vidi: „Koncèsija”, u: KLAIĆ, Rječnik stranih riječi, 720.
} 
Kraljevske zemaljske vlade u Zagrebu na raspravi je bio građevni savjetnik Đuro Augustin, a od zastupnika molitelja dozvole dr. Lavoslav Šram i Franjo Peyer iz Zagreba. ${ }^{38}$

Na molbu grofa Artura Berchtolda, predsjednika povjerenstva za izgradnju željeznice Dugo Selo - Novska, kraljevski ugarski ministar trgovine odredio je 21. veljače 1894. pod br. 12991/III da se politički ophod krilne pruge Piljenice - Pakrac održi 7. - 8. ožujka 1894. godine. Voditelj toga ophoda bio je ministerijalni tajnik Vladimir Ehrenhöfer. Na ophodu su predstavnici zainteresiranih općina predložili da se naziv željezničke postaje u Piljenicama promijeni u Banova Jaruga-Piljenice. ${ }^{39}$

Izvješće Bjelovarsko-križevačke županije iz 1895. spominje da se uz već izgrađenu vicinalnu željeznicu Bjelovar - Križevci ${ }^{40}$ intenzivno radi na tome da se izgradi i pruga Dugo Selo - Novska. Rasprave o njezinoj izgradnji bile su gotovo dogotovljene te je bilo predviđeno da radovi počnu u rano proljeće $1896 .{ }^{41}$ Iste godine Požeška županija u svojem izvješću potvrđuje da će se tijekom 1896. pristupiti dugo očekivanoj izgradnji pruge Novska - Dugo Selo s ogrankom Piljenice - Pakrac. ${ }^{42}$

Naknadni politički ophod Lonjskopoljske željeznice određen je otpisom kraljevskoga ugarskog ministra trgovine od 5. ožujka 1896. pod brojem 13586/ III, a održan 28. ožujka 1896. i idućih dana. Na ophodu su razmatrane varijante na glavnoj pruzi između Popovače i Lipovljana te na krilnoj pruzi Banova Jaruga - Pakrac. Ophodu su nazočili predstavnici kraljevskoga ugarskog ministra trgovine (Vladimir Ehrenhöfer kao voditelj ophodnoga povjerenstva), Carskoga i kraljevskoga zajedničkog ministarstva rata, bana Kraljevine Hrvatske, Slavonije i Dalmacije, Kraljevske požeške županijske oblasti, kraljevskih kotarskih oblasti u Pakracu, Daruvaru, Novskoj i Kutini, Kraljevske županijske oblasti u Bjelovaru, Kraljevskih ugarskih državnih željeznica, kraljevskih

\footnotetext{
38 HR-HDA-79-UOZV, kut. 898, sv. 10-4, ur.br. 835/1888. Nažalost, zapisnik se ne nalazi unutar predmetnih dokumenata.

39 HR-HDA-79-UOZV, kut. 2856, predmet X. 1898/204, sv. 10-4, kor.br. 10484/1894. Usp. „Željezničke stvari”, Glasnik županije Požežke (Požega), 17. 3. 1894., 3. Usp. i: SOHR, „Gradnja željezničkih pruga”, 124-125. Prema navedenom autoru, ujesen 1893. Povjerenstvo za ispitivanje odnošaja ugljenokopa u Ugarskoj i Hrvatskoj, koje je imalo svoje sjednice pri Kraljevskom ugarskom ministarstvu trgovine u Budimpešti, odlučilo je o izgradnji pruge Dugo Selo - Novska. Početkom 1894. pruga je dobila odobrenje. U Glasniku županije Požežke željeznička postaja navodi se pod nazivom „Banovajaruga-Piljenica”.

40 Vicinalna pruga Križevci - Bjelovar puštena je u promet 12. rujna 1894. godine. Vidi: LAJNERT, „Dioničarsko društvo vicinalne željeznice Križevci - Bjelovar - Virovitica - Barcs”, 16.

${ }_{41} \quad$ Izvještaj Upravnog odbora županije belovarsko-križevačke o stanju uprave i kr. županijske oblasti, o njenom djelovanju i područnih joj kr. kotarskih oblasti u godini 1895., 13.

42 Izvješće upravnoga odbora županije požežke o poslovanju za godinu 1895., 57. U svibnju 1896. Šumarski list potvrdio je informaciju da se s gradnjom pruge Novska - Dugo Selo započelo u proljeće. Vidi: „Sitnice”, Šumarski list, 1. 5. 1896., 200.
} 
ugarskih državnih građevnih ureda u Požegi i Sisku, Društva južne željeznice, Dioničarskoga društva vicinalne željeznice Barcs - Pakrac te molitelja koncesije (Artur Berchtold, Franjo Peyer, Ivan Obad te Ivan Horsky i Vilim Beck). Zapisnik je na kraju ophoda, uz određene primjedbe, potpisan. ${ }^{43}$

Zakonski članak XIII. kojim se dozvoljuje željeznica Lonjske doline s Dozvolnom izpravom za parovoznu željeznicu Lonjske doline izdan je 30. svibnja 1896. godine. Koncesijskom ispravom dobili su grof Berchtold ${ }^{44}$ i njegovi kointeresenti dozvolu te preuzeli obvezu da će glavnu prugu, koja je trebala voditi od postaje Dugo Selo Kraljevskih ugarskih državnih željeznica do postaje Novska Kraljevskih ugarskih državnih željeznica, te krilnu prugu s razgrankom iz glavne pruge kod Banove Jaruge do Pakraca Vicinalne željeznice Barcs - Pakrac kao jedinstvenu parovoznu željeznicu izgraditi i dok traje koncesijska isprava neprekidno držati u prometu. Zapisnik o koncesijskoj raspravi sastavljen je 2. travnja 1895. godine. Koncesionar je bio dužan završiti gradnju željeznice te ju predati javnom prometu za dvije godine računajući od datuma koncesije. Za izgradnju je odobrena državna potpora od 500.000 forinti te je ministar financija ovlašten tu državnu potporu staviti na raspolaganje iz zalihe državne blagajne. Za izgradnju i prometno uređenje dozvoljene željeznice potrebna faktična glavnica ustanovljena je u iznosu od 4.200.000 forinti, od koje su koncesionari bili dužni upotrijebiti za nabavu prometnih sredstava 200.000 forinti. Od faktične glavnice trebalo je izlučiti 45.000 forinti i kao s pričuvom posebno rukovati. Koncesionar je bio dužan prije izdavanja koncesije kod Kraljevske ugarske središnje državne blagajne položiti jamčevinu od 130.000 forinti. Koncesionari su s odobrenjem kraljevskoga ugarskog ministra trgovine poslovodstvo željeznice za čitavo vrijeme trajanja dozvole prenijeli na Ravnateljstvo Kraljevskih ugarskih državnih željeznica. Glede priključenja k postajama Dugo Selo i Novska Kraljevskih ugarskih državnih željeznica te postaji Pakrac Vicinalne željeznice Barcs - Pakrac, koncesionari su bili dužni nagoditi se s Ravnateljstvom Kraljevskih ugarskih državnih željeznica, odnosno Dioničarskim društvom vicinalne željeznice Barcs - Pakrac uz prethodno odobrenje kraljevskoga ugarskog ministra trgovine. Osim priključnih ugovora sa spomenutim željeznicama za zajedničku ili skupnu uporabu postaja, koncesionari su mogli sklopiti s drugim željeznicama i ugovore za zajedničku uporabu pojedinih priključujućih dijelova pruge. I za njih je trebala dozvola

\footnotetext{
43 HR-HDA-79-UOZV, kut. 2856, predmet X. 1898/204, sv. 10-4, kor.br. 10484/1894., ur.br. $72409 / 1896$.

${ }_{44}$ Koncesionar pruge grof Berchtold dobio je za gradnju pruge izvanrednu državnu pripomoć u iznosu od milijun kruna. Među članovima ravnateljstva spominju se mnogi političari iz Hrvatske i viši državni činovnici. Gorničić-Brdovački u svojem radu kaže da je Berchtold u okolici pruge imao neki posjed, no ne navodi koji. Vidi: GORNIČIĆ-BRDOVAČKI, Razvitak željeznica u Hrvatskoj, 194.
} 
kraljevskoga ugarskog ministra trgovine. Obje vrste ugovora spadale su u tzv. peage pravo. Koncesionari su dobili pravo osnovati dioničarsko društvo. Nakon isteka 90 godina od dana dobivanja koncesije željeznica je trebala besplatno i besteretno prijeći u vlasništvo države. ${ }^{45}$

Ravnateljstvo Kraljevskih ugarskih državnih željeznica objavilo je 24. studenog 1897. u dnevnom tisku vozni red za novu željezničku prugu Dugo Selo - Novska, koji je vrijedio od dana otvorenja. Po danu su polazili mješoviti, a navečer osobni vlakovi. ${ }^{46}$

Naredbom kraljevskoga ugarskog ministra trgovine br. 67.398/III od 13. studenog 1897. određen je tehničko-redarstveni ophod Lonjskopoljske vicinalne željeznice. Zapisnik o ophodu načinjen je u Lipiku 27. studenog 1897. i sljedećih dana. Na ophodu su bili predstavnici kraljevskoga ugarskog ministra trgovine, Kraljevskoga ugarskoga vrhovnog nadzorništva za željeznice i brodarstvo, Poštanskoga i brzojavnoga generalnog ravnateljstva, bana Kraljevine Hrvatske, Slavonije i Dalmacije, Kraljevske županijske oblasti zagrebačke, Kraljevske županijske oblasti bjelovarsko-križevačke, Kraljevske kotarske oblasti u Kutini, Kraljevske županijske oblasti požeške, Kraljevske kotarske oblasti u Novskoj, Kraljevske kotarske oblasti u Daruvaru, Kraljevske kotarske oblasti u Pakracu, Ravnateljstva Kraljevskih ugarskih državnih željeznica, zagrebačkoga Poslovnog upraviteljstva Kraljevskih ugarskih državnih željeznica, Ispostave za kontrolu gradnje, Društva c. i kr. južne željeznice, odnosno Dioničarskoga društva vicinalne željeznice Barcs - Pakrac i Dioničarskoga društva Lonjskopoljske željeznice. Voditelj povjerenstva bio je Vladimir Ehrenhöfer, ministerijalni odsječni savjetnik, kao predstavnik kraljevskoga ugarskog ministra trgovine. Od koncesionara željeznice prisustvovali su Đuro Dedović i Ivan Horsky kao članovi ravnateljstva te disponent Vilim Beck. Cilj ophoda bila je prosudba povjerenstva odgovaraju li gradnja i oprema željeznice u pogledu kvalitete stručnim zahtjevima za kolaudaciju ${ }^{47}$ željeznica. Prilikom toga ophoda povjerenstvo je temeljito izvidjelo donju i gornju gradnju, zgrade i opremu željeznice te pronašlo da sve odgovara odredbama Željezničkoga prometnog reda od 16. studenog 1851. u tolikoj mjeri da se željeznica može sigurno predati prometu. Prije ophoda obavljeno je pokusno opterećenje mostova na pruzi te ustanovljeno da odgovaraju zahtjevima sigurnosti prometa. Postaje za vodu davale su toliko vode koliko je bilo potrebno za građanski promet, osim po-

\footnotetext{
45 Sbornik zakonah i naredabah. Godina 1896., 366-378.

46 „Dugoselo-Novska”, Narodne novine, 24. 11. 1897., 4. Prema nekim autorima, promet na novoizgrađenim prugama odvijao se sve do 1902. samo danju. Usp. BUNIJEVAC, „Povijest”, 7. Neki pak autori decidirano tvrde da su noćni vlakovi na toj pruzi prometovali od samoga početka. Usp. GORNIČIĆ-BRDOVAČKI, Razvitak željeznica u Hrvatskoj, 193.

47 Kolaudácija lat. (collaudare, hvaliti, pohvaliti), odobrenje, potvrda; predaja novog objekta na upotrebu; naš stari izraz: pohvalba. Vidi: „Kolaudácija”, u: KLAIĆ, Rječnik stranih riječi, 705.
} 
staja Dugo Selo i Ivanić. Na njih se voda, prema potrebi, morala dopremati u vodene rezervoare toliko dugo dok se ne izbuše bunari. Troškovi vezani za dopremu vode na postaju Dugo Selo opterećivali su Kraljevske ugarske državne željeznice jer su one preuzele uređenje te postaje, a troškovi za postaju Ivanić išli su na teret Dioničarskoga društva Lonjskopoljske vicinalne željeznice. Na kraju ophoda voditelj povjerenstva dao je na licu mjesta usmenu dozvolu da se željeznica 29. studenog 1897. može predati javnom prometu, i to: iz Dugog Sela vlakom br. 9512, iz Pakraca odnosno Banove Jaruge vlakom br. 9611 odnosno br. $9514 .^{48}$

Dnevni tisak detaljnije je prikazao cijeli tijek otvaranja pruge. Za samo otvorenje sakupili su se izaslanici političkih oblasti i ostali interesenti, a napose su izdvojeni: voditelj povjerenstva Vladimir pl. Ehrenhöfer, odsječni savjetnik u Kraljevskom ugarskom ministarstvu trgovine; nadinspektor Kornel Tólnay; građevni nadsavjetnik Đuro Augustin; upravitelj Poslovnoga upraviteljstva Kraljevskih ugarskih državnih željeznica u Zagrebu Uzor Leitner s inspektorima Ivanom Marsikom i Ivanom Schebelom te nadmjernikom Baudom; nadmjernik Josip Bánki; nadmjernici Elemér Lázár i Ivan Göttman; telegrafski inspektor Dragutin Brosche; nadliječnik dr. Julijo Kepeš; iz Dioničarskoga društva potpredsjednik Đuro Dedović; iz Zagrebačke županije podžupan Márk Aurél Fodróczy, nadmjernik Franjo vitez Ernst; iz Bjelovarsko-križevačke županije predstojnik Adolf Kvasnička i nadmjernik Milan Luterotti; iz Požeške županije tajnik Ostoja Vučković i nadmjernik Stevo Bukl s kotarskim predstojnicima Svetozarom Grubićem, Mijom Makayem i Lukom Burazovićem te mjernikom Arnoldom Mülerom. Redarstveni je ophod započeo u Dugom Selu 27. studenog 1897. u 9 sati. Vlak je vozio do Lipika, gdje je istoga dana bila zajednička večera bez ikakvih formalnosti. Sutradan u 9.30 krenulo je povjerenstvo iz Lipika u Pakrac te natrag do Banove Jaruge i Novske. Narod se duž pruge skupljao da pozdravi novu željeznicu. Povjerenstvo se tek navečer vratilo u Lipik, gdje je bila organizirana zajednička večera koju je priredio poduzetnik gradnje. Osim obilnoga menija što ga je u kupališnom Kursalonu ${ }^{49}$ priredio poduzetnik Dörner, bilo je i dobroga raspoloženja te protokolarnih zdravica. Tako je narodni zastupnik Đuro Dedović nazdravio povjerenstvu te osobito njegovu predsjedniku Ehrenhöferu. Ovaj je pak uzvratio Dedoviću, koji je dao znatan doprinos da se pruga izgradi. Dalje se

\footnotetext{
48 HR-HDA-79-UOZV, KTO, kut. 5482 (13), Zapisnik o tehničko-redarstvenom ophodu Vicinalne željeznice Lonjske doline, 27. 11. 1897. Prema vijestima iz Ivanić-Grada objavljenim u dnevnom tisku, ophodnja željeznice Dugo Selo - Novska obavljena je 27. i 28. studenog 1897. godine. U Ivaniću je povjerenstvo svečano dočekalo mnoštvo ljudi. Prometno ravnateljstvo Kraljevskih ugarskih državnih željeznica obavijestilo je javnost da se 29. studenog 1897. Lonjskopoljska željeznica otvara za javni promet. Usp. „Željeznica Lonjske doline”, Narodne novine, 29. 11. 1897., 4.

49 Zgrada Kursalona reprezentativna je građevina u Lipiku, izgrađena 1893. godine.
} 
nastavio niz zdravica zastupnicima oblasti, poduzetniku gradnje, domovini itd. U ponedjeljak 29. studenog skupilo se povjerenstvo u kupališnoj dvorani radi sastavljanja i potpisivanja zapisnika, prije čega je upriličen prigodni ručak $\left(\right.$ déjeuner $^{50}$ ). Na kraju je predsjednik povjerenstva Ehrenhöfer objavio rezultat ophoda potvrdivši da je pruga sposobna za promet te ju je uime ministra trgovine otvorio. Nakon toga pozvao je članove komisije da potpišu zapisnik. Rad ophodnoga povjerenstva protekao je, kao što je potvrdio i sam Ehrenhöfer, na opće zadovoljstvo te je željeznica odmah predana prometu. Zaslužan za taj uspjeh bio je poduzetnik Ivan Horsky. ${ }^{51}$

Bjelovarsko-križevačka županija u svojem izvješću za 1897. potvrđuje da je vicinalna željeznica Dugo Selo - Novska dotično Pakrac izgrađena te u kasnu jesen 1897. predana prometu. Prolazila je kotarevima Čazma i Kutina, pa je središte županije bilo vezano s jugozapadnom periferijom, dakle s najudaljenijim krajevima. To je išlo u prilog općem prometu pučanstva ne samo te nego i drugih županija, a time i u prilog trgovini i obrtu. ${ }^{52}$ Izvješće Požeške županije iz iste godine također potvrđuje puštanje u promet dotične željeznice. ${ }^{53}$

Ovdje treba spomenuti i doprinose Krajiške investicionalne zaklade ${ }^{54} \mathrm{za}$ izgradnju vicinalnih željezničkih pruga, koji su iznosili 5.190 .000 kruna. Od toga je za prugu Dugo Selo - Novska iz Zaklade subvencionirano 320.000 kruna. ${ }^{55}$ Zaklada je tako bila vlasnica temeljnih dionica Lonjskopoljske vicinalne željeznice u nominalnoj vrijednosti od 320.000 kruna. ${ }^{56}$

\footnotetext{
50 Déjeuner, franc. (čit. deženê), doručak; zajutrak; suvremeno značenje: ručak. Vidi: „Déjeuner”, u: KLAIĆ, Rječnik stranih riječi, 267.

51 „Lonjska željeznica”, Narodne novine, 2. 12. 1897., 4.

52 Izvještaj upravnog odbora županije belovarsko-križevačke o stanju uprave i kralj. županijske oblasti, o njenom djelovanju i djelovanju područnih joj kr. kotarskih oblasti u godini 1897., 15.

53 Izvješće upravnoga odbora županije požežke o poslovanju za godinu 1897., 67.

54 Krajiška investicionalna zaklada osnovana je na temelju carskoga zapovjednog pisma od 8. lipnja 1871. od izvanrednih dohodaka iz državnih šuma u Hrvatsko-slavonskoj vojnoj krajini. Zaklada je financijski podupirala gradnju vicinalnih željeznica u Hrvatskoj i Slavoniji.

55 Uz Lonjskopoljsku, iz Krajiške investicionalne zaklade subvencionirane su sljedeće vicinalne željezničke pruge: Vinkovci - Brčko (1.120.000 kruna), Batrina - Našice - Osijek (800.000 kruna), Vinkovci - Županja (60.000 kruna), Ruma - Klenak (200.000 kruna), Sisak - Vrginmost (900.000 kruna), Vrginmost - Karlovac (976.000 kruna), Vrpolje - Osijek (200.000 kruna), Vinkovci - Osijek (614.000 kruna). Vidi: HR-HDA-757-OP, kut. 3, Iskaz troškova podmirenih iz Krajiške investicionalne zaklade za gradnju željeznica od 30. siječnja 1908.

56 HR-HDA-78-PRZV, kut. 786, sv. 6-14, ur.br. 914/1909. Izvješće Požeške županije za 1898. spominje da je za novu kolodvorsku cestu u Lipovljanima Investicionalna zaklada potrošila 8.200 forinti, a za novi željeznički most preko Pakre u Banovoj Jarugi 25.000 forinti. Usp. Izvješće upravnoga odbora županije požežke o poslovanju za godinu 1898., 75-76.
} 
Interpelacija iznesena na Saboru Kraljevine Hrvatske, Slavonije i Dalmacije u vezi s određivanjem Budimpešte kao sjedišta Lonjskopoljske željeznice

Dana 25. siječnja 1897. održana je 168. sjednica Sabora Kraljevine Hrvatske, Slavonije i Dalmacije. Na sjednici je dr. Ivan Ružic ${ }^{57}$ iznio interpelaciju u vezi s tim što je Dioničarsko društvo Lonjskopoljske željeznice imalo sjedište u Budimpešti. Rekao je da se iz pravila Društva vidi da se na hrvatskom zemljištu gradi željeznička pruga, i to od Dugog Sela do Novske i od Banove Jaruge do Pakraca, te da je za njezinu izgradnju Hrvatska dala veliki novčani doprinos. Unatoč tome, sjedište Društva bilo je u Budimpešti, gdje je i protokolirano, a na temelju čl. 6. Temeljnih pravila poslovni službeni jezik trebao je biti mađarski. Prema riječima dr. Ružića, time se u prvom redu osjetljivo vrijeđa politički individualitet Hrvatske jer se željeznica gradi hrvatskim novcem na hrvatskom teritoriju, a ipak se njezina uprava prenosi u tuđu zemlju. Pritom se ignorira jezik zemlje gdje se željeznica gradi te naroda čijim se znatnim doprinosima gradi. Nadalje se čini velika šteta hrvatskom narodu time što se izigrava porezni doprinos koji bi Hrvatska dobivala od uprave tih željeznica jer je Društvo plaćalo porez ondje gdje mu je sjedište. Naposljetku, prijenos sjedišta Društva u Budimpeštu na štetu je samoga prometa jer je sjedište uprave znatno udaljeno od područja gdje željeznica prometuje. Takvih je slučajeva bilo u Hrvatskoj i Slavoniji više, osobito otkad je banom postao grof Khuen-Héderváry. Prema mišljenju dr. Ružića, ban Héderváry htio je, po želji Mađara, da se hrvatski novac troši za željeznice u korist tuđinca Mađara i da se time hrvatski narod oštećuje i vrijeđa. Na kraju svoje interpelacije, s obzirom na to da se željeznica gradila znatnim hrvatskim doprinosima, da je Društvo imalo sjedište u Budimpešti, da mu je naziv glasio mađarski i njemački te da su tako bila uređena i sva ostala željeznička društva u Hrvatskoj i Slavoniji, dr. Ružić je postavio upit Kraljevskoj zemaljskoj vladi u Zagrebu kako ona opravdava taj postupak koji stoji u suprotnosti s materijalnim i narodnim probicima hrvatske kraljevine. $^{58}$

\footnotetext{
57 Dr. Ivan Ružić (Hreljin kod Bakra, 1849. - Zagreb, 22. siječnja 1915.). Odvjetnik i pisac. Gimnaziju je polazio u Senju, Zagrebu i Rijeci. Nakon studija u Parizu, Heidelbergu i Berlinu, u Beču je položio doktorat prava. Ban Ivan Mažuranić pozvao ga je 1874. u povjerenstvo stručnjaka zaduženih za predlaganje mjera za promicanje gospodarstva u Hrvatskoj. Godine 1876. postao je odvjetnik i javni bilježnik u Bjelovaru, gdje je ostao više godina. U Bjelovaru je postao utemeljitelj i vođa Stranke prava. Nakon toga se preselio u Zagreb kao javni branitelj. Zapamćen je i kao govornik u Hrvatskom saboru, gdje je zastupao koprivnički izborni kotar ispred Starčevićeve stranke prava (domovinaši). Bio je u vodstvu te stranke i jedan od važnijih ljudi u vodstvu stranke nakon raskola pravaša 1895. godine. Vidi: KARAULA, „Bjelovar u memoarima velikog župana”, 172.

58 HR-HDA-78-PRZV, kut. 1183, Interpelacije, ur.br. 138/1897.
} 
Interpelacija je 28. siječnja 1897. poslana banu Khuen-Héderváryju. Među ostalim, ban je u svojem odgovoru istaknuo da je jednodušni zahtjev koncesionara željeznice bio da sjedište Dioničarskoga društva bude u Budimpešti. Koncesionari su to zahtijevali iz čisto praktičnih razloga (financijskih i upravnih) jer su sve financijske ustanove i državna tijela koja su bila nadležna za poslovanje Društva imala sjedište u Budimpešti. Prema banovim riječima, naziv Društva ustanovljen je nakon koncesijske rasprave te je i uvršten u Zakonski članak XIII. iz 1896. i pripadajuću koncesiju. Uvrštenje naziva tvrtke na hrvatskom jeziku u trgovačku knjigu, prema njemu, nije ništa mijenjalo na stvari. I na kraju, u koncesiji nije bilo spomenuto da je službeni jezik društva mađarski. ${ }^{59}$ Ban se pozvao na čl. 56. Hrvatsko-ugarske nagodbe iz 1868., po kojem je na cijelom teritoriju Kraljevine Hrvatske i Slavonije službeni jezik hrvatski. ${ }^{60}$ Ta obveza, prema banovim riječima, postojala je i za Dioničarsko društvo Lonjskopoljske vicinalne željeznice, Ravnateljstvo Kraljevskih ugarskih državnih željeznica, kao i za sva željeznička društva koja su djelovala unutar Kraljevine. ${ }^{61}$

\section{Upravna tijela Dioničarskoga društva Lonjskopoljske željeznice}

U ovom poglavlju navedeni su, kao primjer, članovi uprave Dioničarskoga društva Lonjskopoljske željeznice za 1897., 1899., 1902., 1905., 1909. i 1913. godinu.

Na dan 31. prosinca 1897. sjedište Društva bilo je na adresi Budimpešta, VI., Béla-utcza 1.

Ravnateljstvo je bilo u sastavu: predsjednik grof Arthur Berchtold, potpredsjednici György Dedovich i Jakab Haas te članovi Márk Cuvaj, Tivadar Georgievic, dr. Svetislav Sumanovic, Beimel Sándor, Illés Györgyei, Emil Haas, dr. Rafael Neumann, János Horsky, Gyula Soltz, István Téglássy i Augustin György.

\footnotetext{
59 U koncesiji od 30. svibnja 1896. zaista se ne spominje da je mađarski službeni jezik Dioničarskoga društva Lonjskopoljske željeznice. Vidi: Sbornik zakonah i naredabah. Godina 1896., 367378. Međutim, mađarski se kao službeni poslovni jezik toga društva spominje u čl. 6. Temeljnih pravila Dioničarskoga družtva Lonjskopoljske željeznice iz 1896. godine. Vidi: HR-HDA-78-PRZV, kut. 499, sv. 6-14, ur.br. 2983/1896.

60 Na temelju čl. 56. Nagodbe, na cjelokupnom prostoru Kraljevine Hrvatske i Slavonije, i u zakonodavstvu i u sudstvu i upravi, službeni jezik bio je hrvatski. Vidi: „Zakonski članak o nagodbi, koju s jedne strane kraljevine Ugarska, sjedinjena s Erdeljem, s druge strane kraljevine Hrvatska i Slavonija, sklopiše za izravnanje postojavših izmedju njih državnopravnih pitanja od 8. studenoga 1868.", Sbornik zakonah i naredabah. Godina 1868., 115-125.

${ }_{61}$ HR-HDA-78-PRZV, kut. 1183, Interpelacije, ur.br. 138/1897.
} 
Članovi nadzornoga odbora bili su Imre Birnbaum, Hector Catinelli, Adolf Herzl, N. A. Plavšić i dr. Aurél Neumann (zamjenik). ${ }^{62}$

Na dan 31. prosinca 1899. sjedište Društva bilo je u Budimpešti, VI., Váczi-körut 37.

Ravnateljstvo je bilo u sljedećem sastavu: predsjednik grof Arthur Berchtold, potpredsjednici György Dedovich i Jakab Haas te članovi Augustin György, Beimel Sándor, Márk Cuvaj, Tivadar Georgievic, Illés Györgyei, Emil Haas, János Horsky, dr. Rafael Neumann, Gyula Soltz, dr. Svetislav Sumanovic i István Téglássy.

Članovi nadzornoga odbora bili su Imre Birnbaum, Hector Catinelli, Adolf Herzl, N. A. Plavšić i dr. Aurél Neumann (zamjenik). ${ }^{63}$

Na dan 31. prosinca 1902. sjedište Društva bilo je u Budimpešti, V., Lipót-körut 3.

Ravnateljstvo su činili predsjednik grof Arthur Berchtold, potpredsjednici Györgyei Dedovich i Jenő Szabó te članovi Augustin György, Slavko Cuvaj, Beni Enyedy, Illés Györgyei, János Horsky, Lajos Jellinek, dr. Gyula Kelemen, dr. Moriz Mezei, dr. Zoltán Okolicsányi, Gyula Sóltz, István Téglássy i Franz Vas. Prokurist je bio János Kárpáti.

Članovi nadzornoga odbora bili su Hector Catinelli, Miksa Fehér, Adolf Herzl i N. A. Plavšić. ${ }^{64}$

Na dan 31. prosinca 1905. sjedište Društva bilo je u Budimpešti, V., Lipót-körut 3.

Ravnateljstvo je bilo u sastavu: predsjednik grof Arthur Berchtold, potpredsjednici György Dedovich i Jenő Szabó te članovi György Augustin, Beni Enyedy, János Horsky, Lajos Jellinek, dr. Gyula Kelemen, Dragutin Krsnjavi, dr. Mór Mezei, dr. Zoltán Okolicsányi, Gustav Tavi ${ }^{65}$, István Téglássy, grof Sándor Teleki, Gyula Tomcsányi i Franz Vas.

\footnotetext{
62 Mihók'scher Ungarischer Compass, 1898./9., 466. U svim onodobnim službenim shematizmima sva imena i prezimena, bez obzira na etničko podrijetlo, mađarizirana su te napisana u skladu s mađarskom jezično-pravopisnom normom.

63 Mihók'scher Ungarischer Compass, 1900./1901., 419-420. Usp. Compass. Finanzielles Jahrbuch für Oesterreich-Ungarn, 1901., 1223-1224.

${ }_{64}$ Compass. Finanzielles Jahrbuch für Oesterreich-Ungarn, 1904., 968-969.

65 Gustav Tavi spominje se kao član ravnateljstva u austrijskom službenom shematizmu, ali u mađarskom shematizmu ne.
} 
Članovi nadzornoga odbora bili su Hector Catinelli, Miksa Fehér, Adolf Herzl, N. A. Plavšić, Gyula Szekula i Adolf Kovács kao zamjena. Prokuristi su bili Béla Hoffer i Miklós Domokos, a računovođa Henrik Darilek. ${ }^{66}$

Na dan 31. prosinca 1909. sjedište Društva bilo je u Budimpešti, V., Mérleg-utcza 3.

U Ravnateljstvu su bili predsjednik grof Arthur Berchtold, potpredsjednici György Dedovich i Jenő Szabó te članovi Ivan Hérvoić, Lajos Jellinek, grof Sándor Teleki, János Horsky, dr. Gyula Kelemen, dr. Mór Mezei, dr. Zoltán Okolicsányi, Gyula Tomcsányi, Ferencz Vas, Ákos Boór, Béla Hoffer, Gyula Junkovich, Richárd Lessner i Ármin Rosenberg.

Članovi nadzornoga odbora bili su dr. Károly Fuchs, László Neugebauer, Miksa Fehér, N. A. Plavšić i Gyula Szekula. Zamjena je bio Adolf Kovács, prokurist Miklós Domokos, a računovođa Henrik Darilek. ${ }^{67}$

Na dan 31. prosinca 1913. sjedište Društva bilo je u Budimpešti, V., Mérleg-utcza 3.

Ravnateljstvo je bilo u sastavu: predsjednik grof Arthur Berchtold, potpredsjednik Jenő Szabó te Vladimir Bacsinszky, Lajos Jellinek, grof Sándor Teleki, dr. Gyula Kelemen, Mór Mezei, dr. Zoltán Okolicsányi, dr. József Kovács, Ákos Boór, Béla Hoffer, Gyula Junkovich, dr. Richárd Lukács-Lessner, Ármin Rosenberg, Miklós Domokos, Béla Kisfaludi Lipthay, Vincze Nagy i Márk Aurél Fodróczy.

Članovi nadzornoga odbora bili su Márton Benkő, dr. Károly Fuchs, László Neugebauer, Miksa Fehér, Gyula Szekula i Adolf Kovács (zamjena).

Članovi izvršnoga odbora bili su Jenő Szabó, Lajos Jellinek, Mór Mezei, Béla Hoffer, dr. Richárd Lukács-Lessner i dr. Gyula Kelemen. ${ }^{68}$

Najdugovječniji član uprave bio je grof Arthur Berchtold, predsjednik Društva i glavni koncesionar. Svi ostali bili su članovi dulje ili kraće vrijeme. Ban je imao pravo imenovanja jednoga člana u ravnateljstvo Lonjskopoljske vicinalne željeznice, koji je zastupao Krajišku investicionalnu zakladu. Tako je npr. 1909. banov zastupnik u ravnateljstvu Lonjskopoljske željeznice bio Ivan pl. Hervoić, odsječni savjetnik (odluka bana br. 914 Pr. od 16. ožujka 1909.). ${ }^{69}$ S obzirom na doprinose županija, gradova i imovnih općina, zasluge pojedi-

\footnotetext{
66 Compass. Finanzielles Jahrbuch für Oesterreich-Ungarn, 1907., 1128-1129. Usp. Mihók'scher Ungarischer Compass, 1906.-1907., 549-550.

${ }_{67} \quad$ Mihók'scher Ungarischer Compass, 1910.-1911., 905-906.

68 Ungarischer Compass, 1914.-1915., 1069.

69 HR-HDA-78-PRZV, kut. 786, sv. 6-14, ur.br. 914/1909.
} 
naca, kao i na temelju dobrovoljnoga biranja na glavnoj skupštini, u ravnateljstvima vicinalnih željeznica nalazili su se i domaći ljudi. Tako je npr. 1909. u ravnateljstvu Lonjskopoljske željeznice bio veliki župan Gyula Junkovich. ${ }^{70}$ Svi spomenuti članovi uprave govore nam o tome da je osim lokalnoga u tu željeznicu bio uložen i znatan mađarski kapital. To je i razumljivo s obzirom na to da je sva upravna i financijska vlast nad željeznicama bila koncentrirana u Budimpešti. Sva dionička društva vicinalnih željeznica na prostoru Kraljevine Hrvatske i Slavonije imala su sjedište u Budimpešti ${ }^{71}$, a apsolutni nadzor nad svim segmentima postupka izgradnje i eksploatacije vicinalnih željeznica u Kraljevini Hrvatskoj i Slavoniji (sazivanje koncesijskih rasprava, izdavanje koncesija, odobravanje projekata, izdavanje građevinskih i uporabnih dozvola i sl.) imao je kraljevski ugarski ministar trgovine u Budimpešti.

\section{Poslovanje Dioničarskoga društva Lonjskopoljske željeznice}

Nedugo nakon što su krajem 1897. otvorene za promet pruge Lonjskopoljske željeznice, Bjelovarsko-križevačka županija u svojem je izvješću iznijela podatak da željeznica Dugo Selo - Novska - Pakrac povoljno utječe na razvoj izvozne trgovine. ${ }^{72}$ Prema Iskazu o izvozu i uvozu na nekim vicinalnim željeznicama u Hrvatskoj 1901. i 1903., na Lonjskopoljskoj željeznici najviše se otpremalo građevno piljeno drvo, zatim glina, zemlja, pijesak, kamen, šljunak, onda ogrjevno drvo, a manje rogata marva, željezna roba, opeka i crijep, vino, mošt, kameni ugljen itd. Godine 1901. otpremljeno je prugom Novska - Dugo Selo - Zagreb oko 4800 vagona drvene robe, a drvenoga ugljena oko 500 vagona. Godine 1903. otpremljeno je tom prugom oko 3500 vagona drvene robe, a izvoz drvenoga ugljena pao je na 350 vagona. ${ }^{73}$

Prema objavljenim državnim statističkim podacima, Lonjskopoljska željeznica imala je od 1897. do 1910. sljedeće eksploatacijske rezultate: ${ }^{74}$

\footnotetext{
70 Isto.

${ }^{71}$ Iznimka je bilo Dioničarsko društvo Rumsko-vrdničke lokalne željeznice, koje je imalo sjedište u Zagrebu. Vidi: LAJNERT, „Dioničarsko društvo Slavonske vicinalne željeznice”, 159.

72 Izvještaj upravnog odbora i kr. županijske oblasti županije bjelovarsko-križevačke o stanju uprave i njihovom djelovanju u godini 1898., 82.

73 GORNIČIĆ-BRDOVAČKI, Razvitak željeznica u Hrvatskoj, 193-194, Prilog 2.

74 Statistički godišnjak Kraljevina Hrvatske i Slavonije, 1905., 654-655 i Statistički godišnjak Kraljevina Hrvatske i Slavonije, 1906-1910., 479-480. U službenim državnim statistikama željeznica se naziva Vicinalna željeznica Lonjska dolina ili D. Lonja željeznica (Lonja-T. Bahn).
} 


\begin{tabular}{|r|r|r|r|r|}
\hline Godina & $\begin{array}{l}\text { Broj preveze- } \\
\text { nih putnika }\end{array}$ & $\begin{array}{l}\text { Prevaljeni putnički } \\
\text { kilometri }(\mathrm{pkm})^{75}\end{array}$ & $\begin{array}{l}\text { Otpremljeno } \\
\text { robe (dobara) u } \\
\text { tonama }\end{array}$ & $\begin{array}{l}\text { Prevaljeni tonski } \\
\text { kilometri }(\mathrm{tkm})^{76}\end{array}$ \\
\hline 1897. & 11000 & 275000 & 5000 & 174000 \\
\hline 1898. & 182000 & 4978000 & 45000 & 1973000 \\
\hline 1899. & 181000 & 5324000 & 71000 & 2311000 \\
\hline 1900. & 169000 & 4945000 & 77000 & 2499000 \\
\hline 1901. & 193000 & 5741000 & 109000 & 4196000 \\
\hline 1902. & 185000 & 5222000 & 87000 & 3201000 \\
\hline 1903. & 216000 & 6304000 & 80000 & 2960000 \\
\hline 1904. & 220000 & 6179000 & 95000 & 3632000 \\
\hline 1905. & 258000 & 7275000 & 115000 & 5245000 \\
\hline 1906. & 290000 & 7926000 & 116000 & 5105000 \\
\hline 1907. & 282000 & 7804000 & 129000 & 5521000 \\
\hline 1908. & 279000 & 7746000 & 147000 & 6309000 \\
\hline 1909. & 299000 & 8492000 & 123000 & 7135000 \\
\hline 1910. & 355000 & 9892000 & 135000 & 7597000 \\
\hline
\end{tabular}

Pogledajmo eksploatacijske rezultate nekih drugih dioničarskih društava vicinalnih željeznica na prostoru Kraljevine Hrvatske i Slavonije za 1906. godinu.: $:^{77}$

\begin{tabular}{|l|r|r|r|r|}
\hline \multicolumn{1}{|c|}{ Vicinalna željeznica } & $\begin{array}{c}\text { Broj preve- } \\
\text { zenih put- } \\
\text { nika }\end{array}$ & $\begin{array}{c}\text { Prevaljeni putnički } \\
\text { kilometri (pkm) }\end{array}$ & $\begin{array}{c}\text { Otpremljeno } \\
\text { robe (dobara) u } \\
\text { tonama }\end{array}$ & $\begin{array}{l}\text { Prevaljeni tonski } \\
\text { kilometri (tkm) }\end{array}$ \\
\hline Vinkovci - Brčko & 105000 & 2962000 & 125000 & 4327000 \\
\hline Varaždin - Golubovec & 105000 & 1752000 & 118000 & 2677000 \\
\hline $\begin{array}{l}\text { Slavonska vicinalna } \\
\text { željeznica }\end{array}$ & 393000 & 10275000 & 308000 & 14208000 \\
\hline $\begin{array}{l}\text { Križevci - Bjelovar - } \\
\text { Virovitica - Barcs }\end{array}$ & 373000 & 8267000 & 173000 & 4702000 \\
\hline $\begin{array}{l}\text { Szt. Lörincz - Slatina - } \\
\text { Našice }\end{array}$ & 370000 & 7507000 & 274000 & 8691000 \\
\hline Ruma - Klenak & 98000 & 1884000 & 26000 & 698000 \\
\hline $\begin{array}{l}\text { Vinkovci - Županja - } \\
\text { savska obala }\end{array}$ & 73000 & 1363000 & 37000 & 990000 \\
\hline $\begin{array}{l}\text { Osijek - Đakovo - Vr- } \\
\text { polje }\end{array}$ & 211000 & 4465000 & 85000 & 1983000 \\
\hline Ruma - Vrdnik & 19000 & 341000 & 174000 & 2986000 \\
\hline Barcs - Pakrac & 254000 & 6676000 & 244000 & 12267000 \\
\hline Zagreb - Samobor & 190000 & 2516000 & 11000 & 219000 \\
\hline
\end{tabular}

75 Putnički kilometar je mjerna jedinica koja izražava prijevoz jednoga putnika na udaljenosti od $1 \mathrm{~km}$.

76 Tonski kilometar je mjera koja se upotrebljava u prometu tereta i pokazuje transportni učinak teretnih vozila. Dobiva se kao umnožak mase prevezenoga tereta i prijeđenih kilometara. Konkretnije, tonski kilometar je mjerna jedinica koja izražava prijevoz 1 tone robe na udaljenosti od $1 \mathrm{~km}$.

77 Statističkigodišnjak Kraljevina Hrvatske i Slavonije, 1905., 654-655 i Statistički godišnjak Kraljevina Hrvatske i Slavonije, 1906-1910., 479-480. 
Dionički kapital i dobitak Lonjskopoljske željeznice između 1897. i 1914. iznosio je: ${ }^{78}$

\begin{tabular}{|l|r|r|}
\hline \multicolumn{1}{|c|}{ Datum } & Dionička glavnica & \multicolumn{1}{c|}{ Čisti dobitak } \\
\hline 31. prosinca 1897. & 4.970 .000 forinti & 4.974 forinte \\
\hline 31. prosinca 1899. & $9.940 .000 \mathrm{kruna}^{79}$ & $127.000 \mathrm{kruna}$ \\
\hline 31. prosinca 1901. & $9.940 .000 \mathrm{kruna}$ & $188.104 \mathrm{kruna}$ \\
\hline 31. prosinca 1902. & $9.940 .000 \mathrm{kruna}$ & $183.737 \mathrm{kruna}$ \\
\hline 31. prosinca 1904. & $9.940 .000 \mathrm{kruna}$ & $196.605 \mathrm{kruna}$ \\
\hline 31. prosinca 1905. & $9.940 .000 \mathrm{kruna}$ & $223.051 \mathrm{kruna}$ \\
\hline 31. prosinca 1906. & $9.940 .000 \mathrm{kruna}$ & $213.421 \mathrm{kruna}$ \\
\hline 31. prosinca 1907. & $9.940 .000 \mathrm{kruna}$ & $218.693 \mathrm{kruna}$ \\
\hline 31. prosinca 1908. & $9.940 .000 \mathrm{kruna}$ & $248.889 \mathrm{kruna}$ \\
\hline 31. prosinca 1909. & $9.940 .000 \mathrm{kruna}$ & $266.686 \mathrm{kruna}$ \\
\hline 31. prosinca 1910. & $9.940 .000 \mathrm{kruna}$ & $354.240 \mathrm{kruna}$ \\
\hline 31. prosinca 1911. & $9.940 .000 \mathrm{kruna}$ & $366.586 \mathrm{kruna}$ \\
\hline 31. prosinca 1912. & $9.940 .000 \mathrm{kruna}$ & $384.980 \mathrm{kruna}$ \\
\hline 31. prosinca 1913. & $9.940 .000 \mathrm{kruna}$ & $368.241 \mathrm{kruna}$ \\
\hline 31. prosinca 1914. & $9.940 .000 \mathrm{kruna}$ & $297.306 \mathrm{kruna}$ \\
\hline
\end{tabular}

78 Mihók'scher Ungarischer Compass, 1898./9., 466; Mihók'scher Ungarischer Compass, 1900./1901., 419-420; Compass. Finanzielles Jahrbuch für Oesterreich-Ungarn, 1901., 1223-1224; Compass. Finanzielles Jahrbuch für Oesterreich-Ungarn, 1903., 1909; Compass. Finanzielles Jahrbuch für Oesterreich-Ungarn, 1904., 968-969; Mihók'scher Ungarischer Compass, 1905.-1906., 499-500; Compass. Finanzielles Jahrbuch für Oesterreich-Ungarn, 1907., 1128-1129; Mihók'scher Ungarischer Compass, 1906.-1907., 549-550; Mihók'scher Ungarischer Compass, 1907.-1908., 735736; Mihók'scher Ungarischer Compass, 1908.-1909., 795-796; Mihók'scher Ungarischer Compass, 1909.-1910., 842; Mihók'scher Ungarischer Compass, 1910.-1911., 905-906; Mihók'scher Ungarischer Compass, 1911.-1912., 991-992; Mihók'scher Ungarischer Compass, 1912.-1913., 979; Ungarischer Compass, 1913.-1914., 996; Ungarischer Compass 1914.-1915., 1069; Ungarischer Compass, 1915.-1916., 1035-1036.

79 Dionički kapital iznosio je 9.940 .000 kruna, podijeljen na 7350 komada temeljnih dionica (2.940.000 kruna) i 17500 komada prvenstvenih dionica (7.000.000 kruna) po 400 kruna. Zakonskim člankom XXXVI. o uvođenju obće obvezatnoga računanja u krunskoj vrednoti od 21. rujna 1899., krunska vrednota koja je ustanovljena Zakonskim člankom XVII. iz 1892. stupila je na snagu od 1. siječnja 1900. kao jedina i isključiva zakonska vrednota na mjesto austrijske vrednote. Jedan forint austrijske vrednote računao se kao 2 krune, a jedan novčić austrijske vrednote kao 2 filira. Usp. Sbornik zakonah i naredabah. Godina 1899., 893-898. Tako je dotadašnja uplaćena dionička glavnica od 4.970.000 forinti preinačena na 9.940 .000 kruna. 
Pogledajmo za usporedbu dionički kapital i dobitak nekih drugih dioničarskih društava vicinalnih željeznica na prostoru Kraljevine Hrvatske i Slavonije za 1912. godinu: ${ }^{80}$

\begin{tabular}{|l|c|r|r|}
\hline \multicolumn{1}{|c|}{ Vicinalna željeznica } & Osnivanje društva & \multicolumn{1}{c|}{$\begin{array}{c}\text { Dionička } \\
\text { glavnica (u } \\
\text { krunama) }\end{array}$} & $\begin{array}{c}\text { Čisti } \\
\text { dobitak (u } \\
\text { krunama) }\end{array}$ \\
\hline Čakovec - Zagreb & 1885. & 12.400 .000 & 78.736 \\
\hline $\begin{array}{l}\text { Sjedinjene drava-posavske } \\
\text { vicinalne željeznice }\end{array}$ & 15. listopada 1906. ${ }^{81}$ & 10.883 .000 & 375.129 \\
\hline $\begin{array}{l}\text { Prva jugozapadna krajiška } \\
\text { mjesna željeznica }\end{array}$ & 26. svibnja 1902. ${ }^{82}$ & 21.230 .600 & 258.778 \\
\hline $\begin{array}{l}\text { Križevci - Bjelovar - Viro- } \\
\text { vitica - Barcs }\end{array}$ & 1893. & 22.893 .200 & 438.288 \\
\hline Petrovaradin - Beočin & 1907. & 3.037 .800 & 84.384 \\
\hline Ruma - Klenak & 1901. & 2.620 .400 & 45.395 \\
\hline $\begin{array}{l}\text { Szt. Lörincz - Slatina - Na- } \\
\text { šice }\end{array}$ & 1894. & 10.199 .200 & 460.543 \\
\hline $\begin{array}{l}\text { Slavonsko-podravska želje- } \\
\text { znica }\end{array}$ & 1900. & 13.972 .600 & 458.465 \\
\hline $\begin{array}{l}\text { Slavonska vicinalna želje- } \\
\text { znica }\end{array}$ & 1892. & 3.580 .000 & 36.669 \\
\hline Varaždin - Golubovec & 1888. & 4.958 .800 & 174.360 \\
\hline Vinkovci - Brčko & 1886. & 500.385 \\
\hline
\end{tabular}

Uspoređujući eksploatacijske rezultate i financijske pokazatelje Lonjskopoljske željeznice s nekim drugim hrvatsko-slavonskim vicinalnim željeznicama, možemo zaključiti da je po broju prevezenih putnika i čistom dobitku to dioničarsko društvo bilo među uspješnijim željeznicama, a po količini otpremljene robe i veličini dioničke glavnice na nešto nižemu mjestu. S obzirom na to da je financijski profit ipak najvažniji parametar za mjerenje uspješnosti nekoga trgovačkog društva, možemo zaključiti da je to dioničarsko društvo ipak bilo važna, uspješna i rentabilna privatna vicinalna željeznica i ulaganje u nju sasvim se isplatilo.

\footnotetext{
$80 \quad$ Ungarischer Compass, 1913.-1914., 975-976, 980-981, 995-996, 1009, 1013, 1019-1022, 1030-1032.

81 Društvo je osnovano 15. listopada 1906. spajanjem Dioničarskoga društva mjestne željeznice Vinkovci - Županja - savska obala (Vinkovce-Županja-Save-Ufer L.-E.-Bahn) i Društva mjestne željeznice Osijek - Đakovo - Vrpolje (Eszék-Djakovár-Vrpoljeer L.-E.-Bahn). Usp. Compass. Finanzielles Jahrbuch Jugoslawien-Ungarn, 1923., 557.

82 „Utemeljenje dioničarskog družtva Prve jugo-zapadne krajiške lokalne željeznice”, Narodne novine, 30. 5. 1902., 5.
} 
Upravno i poslovodno osoblje na postajama Lonjskopoljske željeznice 1918. godine

Kraljevska zemaljska vlada u Zagrebu tiskala je redovito svake godine imenike dostojanstvenika, činovnika i javnih službenika Kraljevine Hrvatske i Slavonije. U imenicima je nabrojeno i upravno i poslovodno osoblje na hrvatsko-slavonskim željeznicama. U ovom je poglavlju kao primjer navedeno poslovodno osoblje na Lonjskopoljskoj željeznici iz 1918. godine. Nažalost, u Imeniku nisu navedene sve postaje te željeznice, a samim time ni svi upravitelji postaja ${ }^{83}$ Treba napomenuti da su pruge Lonjskopoljske željeznice potpadale pod nadležnost Poslovne uprave Kraljevskih ugarskih državnih željeznica u Zagrebu.

Za prugu Dugo Selo - Novska nalazimo sljedeće postaje s upraviteljima: Ivanić-Grad (upravitelj postaje Béla Rajnik), Novoselec-Križ (upravitelj postaje Lajos Mészáros), Moslavina-Popovača (upravitelj postaje Gjuro Vizy), Kutina (upravitelj postaje Zsigmund Lándor), Banova Jaruga (glavar postaje Ljudevit Décsy), Lipovljani (upravitelj postaje Rudolf Hegyi). Za prugu Banova Jaruga - Pakrac navedene su postaje (Pakračka) Poljana (upravitelj postaje Gustav Humsky) i Lipik (upravitelj postaje Imre Hoppe).

U Imeniku se postaja Dugo Selo navodi kao sastavni dio pruge Gyékényes - Rijeka. Spadala je također u nadležnost Poslovne uprave u Zagrebu. Glavar postaje bio je Milić Popović, protustavnik Edo Wimmer, a činovnici János Klug, Gábor Canderlić i Károly Schäffer.

Postaja Novska navodi se kao sastavni dio pruge Sisak - Brod. Spadala je u nadležnost Poslovne uprave u Pečuhu (Pécs). Predstojnik postaje Novska bio je Gyula Veres, a činovnici István Balogh, Ivan Dodigovics, Zoltán Révész i István Magyar.

Pod Poslovnu upravu u Zagrebu spadali su i Inžinirski odsjek u Dugom Selu, koji je služio za održavanje željeznice (predstojnik nadinžinir Vilmos Fink i inžinir János Szilárd), te Grijaonica u Dugom Selu (upravitelj strojonadglednik bio je György Drescher). ${ }^{84}$

\footnotetext{
83 U Imeniku je pod prugom Dugo Selo - Novska navedeno samo osam postaja, od kojih posljednje dvije (Poljana i Lipik) potpadaju pod prugu Banova Jaruga - Pakrac.

${ }^{84}$ Imenik dostojanstvenika, 146-150. Usp. LAJNERT, Ustroj željeznica, 38-39 i VUJASINOVIĆ, Upravno i poslovodno osoblje na željeznicama, 361-363, 370. O odnosu broja hrvatskih i mađarskih zaposlenika na željeznicama u Hrvatskoj vidi: DOBROVŠAK, „Zaposlenici na željeznicama”, 489516 .
} 


\section{Problematika željezničkoga prometa krajem 1918. godine}

Autor u svojem dosadašnjem istraživanju nije naišao na detaljnije podatke o organizaciji željezničkoga prometa na Lonjskopoljskoj željeznici tijekom rata (1914. - 1918.). Ta tema svakako zaslužuje zaseban članak. Najdetaljniji prikaz stanja željezničkoga prometa krajem 1918. na prostoru Hrvatske i Slavonije dao je Vilim Filipašić ${ }^{85}$ u neobjavljenoj zbirci pod nazivom Prevrat godine 1918. i željeznice u Hrvatskoj i Slavoniji. U ovom poglavlju obrađen je samo mali dio službenih telegrama iz te zbirke.

S obzirom na to da je u listopadu 1918. Austro-Ugarska bila pred raspadom, željeznički je promet dospio u veoma nezgodan položaj. Istovremeno je raspad željezničkoga sustava povratno utjecao na ubrzanje raspada države. Pruge po Hrvatskoj i Slavoniji, u Bosni, kod Prometne uprave u Subotici (Szabadka) ${ }^{86}$, dapače oko same Budimpešte bile su zatrpane vagonima koji se nisu mogli otpremiti. Došlo je do pomanjkanja željezničkoga osoblja, promet se reducira, mijenja se red vožnje pojedinih vlakova, promet se dapače potpuno obustavlja. Predviđaju se neredi, pa Ravnateljstvo Kraljevskih ugarskih državnih željeznica u Budimpešti požuruje zagrebačku Prometnu upravu da postaje u njezinoj nadležnosti odmah pošalju glavne mjesečne račune. Neke su pruge u iznimno lošem stanju. Na prostoru Hrvatske i Slavonije sve je više nemira, a i nereda. Po

85 Vilim Filipašić, kao zastupnik hrvatsko-slavonskih željeznica, bio je delegiran pri Ravnateljstvu Kraljevskih ugarskih državnih željeznica u Budimpešti te je samim time bio ne samo svjedok nego i stvaratelj željezničke povijesti. Cjelokupna zbirka sastavljena je od službenih telegrama koji su dostavljani zagrebačkoj Prometnoj upravi Kraljevskih ugarskih državnih željeznica te novoosnovanom zagrebačkom Generalnom ravnateljstvu državnih željeznica SHS, a obuhvaća period od 20. listopada do 5. prosinca 1918. godine. Te su vijesti sačuvane spletom sretnih okolnosti. Dokumenti su pronađeni u svežnjiću koji je bio pohranjen u ormaru, zatvoren u kutu. Inače bi bio uništen ili prodan za makulaturu kao i drugi papiri te vrste stari tri godine. Filipašić je pretražio podrume zagrebačkoga željezničkog ravnateljstva ne bi li možda ondje štogod našao, no bez uspjeha. U podrum je nekoliko puta za vrijeme poplava prodrla voda, koja je usprkos svim nastojanjima namočila i uništila mnoge spise, pa se sa sigurnošću može ustvrditi da je ovdje objelodanjen svežnjić ujedno i sve što je preostalo od telegrama iz onoga doba. Filipašić je sve te vijesti kronološki poredao i preveo jer su željezničke vijesti većim dijelom bile napisane na mađarskom jeziku. Eliminirao je one koje su za pojedine slučajeve manje važne ili su često ponavljane ili nisu sadržavale ništa važno ili nepoznato. Tim podacima dodao je neke važnije telegrame koji su se ticali njegova zastupanja interesa hrvatsko-slavonskih željeznica u Ravnateljstvu Kraljevskih ugarskih državnih željeznica u Budimpešti u studenom i prosincu 1918. ako su rasvjetljavali odnose između dviju željeznica s obzirom na stanje nakon raspada Austro-Ugarske Monarhije. Te vijesti daju sliku događanja i općega stanja i raspoloženja toga doba, stoga su u zbirku uvrštene i one koje same po sebi nisu važne, ali dopunjuju i tumače širu perspektivu. Sve važne vijesti uzete su u zbirku, a isto tako i sve sačuvane vijesti što ih je dobivalo Narodno vijeće (te su vijesti po svoj prilici dojavljene telefonom).

86 Uspostavom Države Slovenaca, Hrvata i Srba pod upravu novoosnovanoga Generalnog ravnateljstva državnih željeznica SHS u Zagrebu spadale su i pruge preuzete od Prometne uprave u Subotici: Petrovaradin - Zemun $(66 \mathrm{~km})$, Batajnica - Boljevci $(28 \mathrm{~km})$ i Vicinalna željeznica Petrovaradin - Beočin (17,4 km). Usp. HR-HDA-881-ZR, inv. br. 638, FILIPAŠIĆ, Vilim. Prevrat godine 1918. i željeznice u Hrvatskoj i Slavoniji, 13. 
postajama se krade, na početku se uništavaju samo mađarski natpisi na postajama, učestali su napadi na željezničko osoblje i postaje, vojnici na proputovanju pucaju iz vlaka, vojnici i građanske osobe čine razne nerede i pljačkaju putnike po postajama i u vlakovima, željezničari mađarske narodnosti šalju svoje obitelji i stvari u Mađarsku, pa i sami ostavljaju svoja službena mjesta i bježe. ${ }^{87}$ Tako je npr. Prometna uprava u Pečuhu ${ }^{88}$ 20. listopada 1918. obavijestila zagrebačku Prometnu upravu da do daljnje odredbe ne preuzima u Novskoj kolnotovarne građanske i vojne pošiljke koje su upućene u Bosanski Brod, osim živih životinja, lako pokvarljive robe i streljiva. ${ }^{89}$ Popović, predstojnik postaje Dugo Selo, telegramom je 21. listopada 1918. obavijestio Prometnu upravu Zagreb da su nepoznati počinitelji 20. listopada ukrali iz vagona dvije tovne svinje. Jedna je svinja pronađena, a drugu su otjerali nekud u selo. Popović je zamolio da se poduzmu mjere da se vojnička straža djelomično izmijeni i nadoknadi od pripadnika tamošnjega oružništva jer su krađe danomice uzimale sve više maha, a straža je, navodno, išla na ruku lopovima. ${ }^{90}$ Dana 27. listopada 1918. Inženjerski odsjek u Dugom Selu obavijestio je Prometnu upravu u Zagrebu da zbog lošega stanja ${ }^{91}$ lonjske vicinalne pruge između Kutine i Banove Jaruge u profilima 610621 mogu do daljnje odredbe svi vlakovi prolaziti samo polako, odnosno s pola brzine. ${ }^{92}$ Istoga dana, s obzirom na općenito pomanjkanje osoblja, Ravnateljstvo Kraljevskih ugarskih državnih željeznica u Budimpešti pozvalo je zagrebačku Prometnu upravu da na prugama u svojoj nadležnosti provede svu moguću redukciju prometa i ukidanje vlakova te na taj način osigura osoblje za bezuvjetno potreban promet. Ravnateljstvo je od Prometne uprave očekivalo hitan odgovor i odgovarajuće prijedloge. ${ }^{93}$ Pandur, službenik postaje Lipik, obavijestio je 28. listopada 1918. zagrebačku Prometnu upravu da se pobunjena masa zajedno s odbjeglim vojnicima pojavila naoružana na postaji, pa su pod prijetnjom smrti zahtijevali od njega da se svi mađarski natpisi uklone te da se odmah izvjesi hrvatska zastava. To je on u strahu za svoj život i učinio. Zamolio je Prometnu upravu da mu iz njegova stana u Zagrebu (udova Šandora Halmija, Šenoina ulica 12) najhitnije pošalju dva obična građanska zimska odijela s kabanicom jer su mu se pobunjeni ljudi grozili oduzimanjem života ako bi i dalje obavljao službu u uniformi. Pobunjenici koji su se toga dana sastali na skupštini ubili su Luku

\footnotetext{
87 Isto, 3-4, 17-34.

88 U nadležnosti Prometne uprave u Pečuhu, među ostalima, bila je i glavna pruga Sisak - Novska - Brod - Vinkovci - Mitrovica - Inđija. Usp. LAJNERT, Ustroj željeznica, 39.

HR-HDA-881-ZR, inv. br. 638, FILIPAŠIĆ, Prevrat godine 1918., 17.

Isto, 17-18.

U dokumentu se koristi izraz rasklimano stanje pruge.

HR-HDA-881-ZR, inv. br. 638, FILIPAŠIĆ, Prevrat godine 1918., 25.

Isto.
} 
Egyeda, željezničkoga pružnog radnika. Smrtni slučaj bio je prijavljen nadležnoj oblasti. ${ }^{94}$

\section{Zaključak}

Željeznička mreža na prostoru nekadašnje Kraljevine Hrvatske i Slavonije najviše se razvila kad je država odlučila njezinu izgradnju i eksploataciju prepustiti privatnom kapitalu, baziranom prvenstveno na ekonomskim interesima. Tako je od donošenja Zakona o željeznicama mjesnog interesa 1880. i njegove dopune iz 1888. pa sve do raspada Austro-Ugarske Monarhije upravo zahvaljujući privatnom kapitalu sagrađena gotovo cjelokupna željeznička mreža na našim prostorima. Analizom objavljenih podataka o poslovanju Lonjskopoljske željeznice u Austro-Ugarskoj Monarhiji te usporedbom s drugim hrvatsko-slavonskim vicinalnim željeznicama, s obzirom na njezinu dioničku glavnicu od 9.940.000 kruna i poslovanje s financijskim dobitkom, možemo zaključiti da je to dioničarsko društvo bilo respektabilna i uspješna privatna vicinalna željeznica. Svojim poslovanjem Društvo je odigralo važnu ulogu u privrednom razvitku područja kojim su prolazile njegove pruge, a u širem kontekstu i cijele Hrvatske i Slavonije. Kako je ta pruga, kao i sve vicinalne željeznice, građena i eksploatirana u prvom redu radi ekonomskih probitaka, odnosno zadovoljavanja gospodarsko-prometnih potreba krajeva kroz koje je prolazila, možemo zaključiti da je potpuno ostvarila svoj cilj. Ulaganje u tu željeznicu u cijelosti se isplatilo. Lonjskopoljska željeznica gradila se znatnim hrvatskim doprinosima, ali dijelom i mađarskim kapitalom, koji je i preko željeznice tražio način za dominaciju nad Hrvatskom i Slavonijom. To se vidi i po članovima uprave te samim zaposlenicima na željeznici, koji su u znatnom broju bili Mađari. Nadasve je to bilo vidljivo u činjenici da se Lonjskopoljska željeznica nalazila na hrvatskom teritoriju, a njezino sjedište, baš kao i svih vicinalnih željeznica u Hrvatskoj i Slavoniji, u Budimpešti.

$94 \quad$ Isto, 33. 


\section{Arhivski i neobjavljeni izvori}

HR-HDA: Hrvatska, Hrvatski državni arhiv, Zagreb:

- fond 78-PRZV: Zemaljska vlada. Predsjedništvo.

- fond 79-UOZV: Zemaljska vlada. Odjel za unutarnje poslove.

- fond 529-HDB: Hrvatska državna banka.

- fond 757-OP: Obitelj Plavšić.

- fond 881-ZR: Zbirka rukopisa.

\section{Objavljeni izvori i tisak}

Compass. Finanzielles Jahrbuch für Oesterreich-Ungarn, 1901., XXXIV. Wien: K. u. k. Hof-und Universitäts-Buchhändler, 1901.

Compass. Finanzielles Jahrbuch für Oesterreich-Ungarn, 1903., XXXVI. Wien: K. u. k. Hof-und Universitäts-Buchhändler, 1902.

Compass. Finanzielles Jahrbuch für Oesterreich-Ungarn, 1904., Band II, XXXVII. Wien: K. u. k. Hof-und Universitäts-Buchhändler, 1903.

Compass. Finanzielles Jahrbuch für Oesterreich-Ungarn, 1907., Band II, XL. Wien: K. u. k. Hof-und Universitäts-Buchhändler, 1906.

Compass. Finanzielles Jahrbuch Jugoslawien-Ungarn, 1923., Band III, LVI. Wien: Compassverlag, 1923.

Glasnik županije Požežke - list za pouku, gospodarstvo, družtveni i javni život (Požega), 1894.

Imenik dostojanstvenika, činovnika i javnih službenika Kraljevina Hrvatske i Slavonije 1918. Zagreb: Kr. hrv.-slav.-dalm. zemaljska vlada, 1918.

Izvješće upravnoga odbora županije požežke o poslovanju za godinu 1895., zatim izvješće kr. podžupana iste županije ob uredovnom djelovanju kr. žup. oblasti u Požegi i područnih joj kr. kotarskih oblasti za vrieme od 1. siečnja do 31. prosinca 1895. Požega: Brzotiskom Lavoslava Kleina, 1896.

Izvješće upravnoga odbora županije požežke o poslovanju za godinu 1897., zatim izvješće kr. podžupana iste županije ob uredovnom djelovanju kr. žup. oblasti u Požegi i područnih joj kr. kotarskih oblasti za vrieme od 1. siečnja do 31. prosinca 1897. Požega: Knjigotiskara Lavoslava Kleina, 1898.

Izvješće upravnoga odbora županije požežke o poslovanju za godinu 1898., zatim izvješće kr. podžupana iste županije ob uredovnom djelovanju kr. žup. oblasti u Požegi i područnih joj kr. kotarskih oblasti za vrieme od 1. siečnja do 31. prosinca 1898. Požega: Knjigotiskara Lavoslava Kleina, 1899. 
Izvještaj upravnog odbora županije belovarsko-križevačke o stanju uprave i kr. županijske oblasti, o njenom djelovanju i područnih joj kr. kotarskih oblasti u godini 1895., podnešen proljetnoj županijskoj skupštini u godini 1896. Bjelovar: Knjigotiskara J. Fleischmanna, 1896.

Izvještaj upravnog odbora županije belovarsko-križevačke o stanju uprave i kralj. županijske oblasti, o njenom djelovanju i djelovanju područnih joj kr. kotarskih oblasti u godini 1897., podnešen proljetnoj županijskoj skupštini u g. 1898. Bjelovar: Knjigotiskara J. Fleischmanna, 1898.

Izvještaj upravnog odbora i kr. županijske oblasti županije bjelovarsko-križevačke o stanju uprave i njihovom djelovanju u godini 1898., podnešen proljetnoj županijskoj skupštini u g. 1899. Bjelovar: Tisak J. Fleischmanna, 1899.

Mihók'scher Ungarischer Compass, 1898./9. Financielles und Commercielles Jahrbuch, II. Theil: Genossenschaft, Assecuranzen, Industrie- u. Verkehrs-Unternehmungen, Staat und Städte, XXVI. Budapest: Buchdruckerei Gebrüder Légrády, 1899.

Mihók'scher Ungarischer Compass, 1900./1901. Financielles und Commercielles Jahrbuch, II. Theil: Genossenschaft, Assecuranzen, Industrie- u. Verkehrs-Unternehmungen, Staat und Städte, XXVIII. Budapest: Buchdruckerei Gebrüder Légrády, 1901.

Mihók'scher Ungarischer Compass, 1905.-1906. Financielles und Commercielles Jahrbuch, II. Theil: Assecuranzen, Industrie- und Verkehrs-Unternehmungen, Staat und Städte-Finazen, XXXIII. Budapest: Stephaneum nyomda r.t., 1906.

Mihók'scher Ungarischer Compass, 1906.-1907. Financielles und Commercielles Jahrbuch, II. Theil: Assecuranzen, Industrie- und Verkehrs-Unternehmungen, Staat und Städte-Finazen, XXXIV. Budapest: Stephaneum Buchdruckerei A.G., 1907.

Mihók'scher Ungarischer Compass, 1907.-1908. Financielles und Commercielles Jahrbuch, II. Theil: Genossenschaften, Assecuranzen, Industrie u. Verkehrs-Unternehmungen, Staats- u. Städte-Finazen, XXXV. Budapest: Stephaneum Buchdruckerei A.G., 1908.

Mihók'scher Ungarischer Compass, 1908.-1909. Financielles und Commercielles Jahrbuch, II. Theil: Genossenschaften, Assecuranzen, Industrie u. Verkehrs-Unternehmungen, Staats- u. Städte-Finazen, XXXVI. Budapest: Stephaneum Buchdruckerei A.G., 1909.

Mihók'scher Ungarischer Compass, 1909.-1910. Financielles und Commercielles Jahrbuch, II. Theil: Genossenschaften, Assecuranzen, Industrie- u. Verkehrs-Unternehmungen, Staats und Städte-Finazen, XXXVII. Budapest: Stephaneum Buchdruckerei A.G., 1910.

Mihók'scher Ungarischer Compass, 1910.-1911. Financielles und Commercielles Jahrbuch, II. Theil: Genossenschaften, Assecuranzen, Industrie- und Verkehrs-Unternehmungen, Staat und Städte-Finazen, XXXVIII. Budapest: Stephaneum Buchdruckerei A.G., 1911. 
Mihók'scher Ungarischer Compass, 1911.-1912. Financielles und Commercielles Jahrbuch, II. Theil: Genossenschaften, Assecuranzen, Industrie- u. Verkehrs-Unternehmungen, Staats- u. Städte-Finazen, XXXIX. Budapest: Stephaneum Buchdruckerei A.G., 1912.

Mihók'scher Ungarischer Compass, 1912.-1913. Financielles und Commercielles Jahrbuch, II. Theil: Assecuranzen, Industrie- $u$. Verkehrs-Unternehmungen, Staats- $u$. Städte-Finazen, XL. Budapest: Stephaneum Buchdruckerei A.G., 1913.

Narodne novine (Zagreb), 1882, 1885, 1888, 1891, 1897, 1902.

Sbornik zakonah i naredabah valjanih za Kraljevine Hrvatsku i Slavoniju. Godina 1868. Zagreb: Tiskara Narodnih novinah, ${ }^{2} 1877$.

Sbornik zakonah i naredabah valjanih za Kraljevinu Hrvatsku i Slavoniju. Godina 1875. Zagreb: Tiskara Narodnih novinah, 1876.

Sbornik zakonah i naredabah valjanih za Kraljevinu Hrvatsku i Slavoniju. Godina 1877. Zagreb: Tiskara Narodnih novinah, 1878.

Sbornik zakonah i naredabah valjanih za Kraljevinu Hrvatsku i Slavoniju. Godina 1880. Zagreb: Tiskara Narodnih novinah, 1881.

Sbornik zakonah i naredabah valjanih za Kraljevinu Hrvatsku i Slavoniju. Godina 1887. Zagreb: Tiskara Narodnih novinah, 1888.

Sbornik zakonah i naredabah valjanih za Kraljevinu Hrvatsku i Slavoniju. Godina 1888. Zagreb: Tiskarski zavod Narodnih novinah, 1888.

Sbornik zakonah i naredabah valjanih za Kraljevinu Hrvatsku i Slavoniju. Godina 1896. Zagreb: Kralj. zemaljska tiskara, 1896.

Sbornik zakonah i naredabah valjanih za Kraljevinu Hrvatsku i Slavoniju. Godina 1899. Zagreb: Kralj. zemaljska tiskara, 1899.

Statistički godišnjak Kraljevina Hrvatske i Slavonije, 1905., I. Zagreb: Kr. zemaljski statistički ured, 1913.

Statistički godišnjak Kraljevina Hrvatske i Slavonije, 1906-1910., II. Zagreb: Kr. zemaljski statistički ured, 1917.

Šumarski list (Zagreb), 1896.

Ungarischer Compass, 1913.-1914. Financielles und Commercielles Jahrbuch, II. Theil: Assecuranzen, Industrie- $u$. Verkehrs-Unternehmungen, Staats- u. Städte-Finazen, XLI. Budapest: Stephaneum Buchdruckerei A.G., 1914.

Ungarischer Compass, 1914.-1915. Financielles und Commercielles Jahrbuch, II. Theil: Assecuranzen, Industrie- $u$. Verkehrs-Unternehmungen, Staats- u. Städte-Finanzen, XLII. Budapest: Stephaneum Buchdruckerei A.G., 1915.

Ungarischer Compass, 1915.-1916. Financielles und Commercielles Jahrbuch, II. Theil: Assecuranzen, Industrie- $u$. Verkehrs-Unternehmungen, Staats- u. Städte-Finazen, XLIII. Budapest: Stephaneum Buchdruckerei A.G., 1916. 


\section{Literatura}

BUNIJEVAC, Helena. „Povijest 'Parovozne lonjsko-poljske željeznice”'. U: Zbornik Povijesnog društva Pakrac - Lipik 5, ur. Stjepan Benković. Pakrac: Povijesno društvo Pakrac - Lipik; Srednja škola Pakrac, 2008, 5-9.

DOBROVŠAK, Ljiljana. „Zaposlenici na željeznicama u Hrvatskoj 1903. godine”. Časopis za suvremenu povijest 40 (2008), br. 2: 489-516.

GORNIČIĆ-BRDOVAČKI, Josip. Razvitak željeznica u Hrvatskoj do 1918. godine. Građenje, organizacija i financijalni odnosi. Zagreb: Jugoslavenska akademija znanosti i umjetnosti, 1952.

KARAULA, Željko. „Bjelovar u memoarima velikog župana Bjelovarske/Bjelovarsko-križevačke županije Budislava pl. Budisavljevića-Prijedorskog 'Pomenci iz moga života”'. Podravina 8 (2009), br. 16: 162-183.

KLAIĆ, Bratoljub. Rječnik stranih riječi: tuđice i posuđenice. Zagreb: Nakladni zavod Matice hrvatske, 2001.

LAJNERT, Siniša. „Dioničarsko društvo Slavonske vicinalne željeznice (1892.-1933.)”. Scrinia Slavonica 19 (2019), br. 1: 159-188.

LAJNERT, Siniša. „Dioničarsko društvo vicinalne željeznice Križevci - Bjelovar Virovitica - Barcs (1893.-1933.)”. CRIS - časopis Povijesnog društva Križevci XX (2018), br. 1: 16-42.

LAJNERT, Siniša. Ustroj željeznica u Hrvatskoj od Austro-Ugarske do danas. Zagreb: HŽ - Hrvatske željeznice, 2003.

SOHR, Miloslav. „Gradnja željezničkih pruga u Požeškoj županiji krajem 19. stoljeća”. Zbornik Janković II (2017), br. 2: 117-126.

STEHLIK, Vladimir. „Postanak i razvitak železnica u Jugoslaviji (s preglednom kartom železničke mreže)”. U: Sto godina železnica Jugoslavije (1849-1949). Zbornik članaka povodom stogodišnjice železnice Jugoslavije, ur. Blagoje Bogavac. Beograd: Redakcija štamparskog preduzeća Jugoslovenskih železnica, 1951, 73-88.

STULLI, Bernard. Prijedlozi i projekti željezničkih pruga u Hrvatskoj 1825-1863, knj. I. Zagreb: Sveučilište u Zagrebu, Institut za hrvatsku povijest, 1975.

VUJASINOVIĆ, Branko. Upravno i poslovodno osoblje na željeznicama u Kraljevini Hrvatskoj i Slavoniji do 1918. Zagreb: HŽ - Holding d.o.o. za poslovne usluge; HŽ - Infrastruktura d.o.o.; Hrvatski željeznički muzej, 2007. 


\section{SUMMARY}

\section{The Structure and the Activity of the Lonjsko Polje Railway Stock Company during the Austro-Hungarian Monarchy}

In the paper the author outlines from the aspect of the history of institutions the structure and the activity of the The Lonjsko Polje Railway Stock Company during the Austro-Hungarian Monarchy. Like the majority of other vicinal railways, the company had its headquarters in Budapest. The stock company was founded on 15 June 1896. The stock company's tasks were performed by: the stockholders' general assembly, headquarters and the inspecting committee. The company's railway lines were: Dugo Selo-Novska and Banova Jaruga-Pakrac. They were put into traffic on 29 November 1897. These private railway lines were exploited i.e. administrated by the state. During the Austro-Hungarian Monarchy the company's railway lines came under the jurisdiction of the Traffic Administration of the Royal Hungarian State Railways in Zagreb. The Novska-Dugo Selo-Zagreb railway track was approximately $12.5 \mathrm{~km}$ shorter than Novska-Sisak-Zagreb, whose Sisak-Zagreb-Savski Marof (Zidani Most) branch was owned by the Southern Railway Society, the biggest and the most powerful railway stock company in the Monarchy. That by default made them competitors. During its construction it was decided to create a transit railway line from the former for the transitional traffic to the detriment of the Southern Railways. By analysing the published information on the business activity of the Lonjsko Polje Railway in the Austro-Hungarian Monarchy and by comparing it with other Croatian-Slavonian vicinal railways, bearing in mind its stock capital of 9.940,000 krone and its operating in the black, it can be concluded that the stock company was a respectable and successful private vicinal railway.

Key words: The Lonjkko Polje Railway; Dugo Selo-Novska railway line; Banova Jaruga-Pakrac railway line; vicinal railways; Austro-Hungarian Monarchy 